IZA DP No. 9961

Permanent Jobs, Employment Protection and Job Content

Lawrence M. Kahn

May 2016 


\title{
Permanent Jobs, Employment Protection and Job Content
}

\author{
Lawrence M. Kahn \\ Cornell University, \\ CESifo, IZA and NCER
}
Discussion Paper No. 9961 May 2016

\author{
IZA \\ P.O. Box 7240 \\ 53072 Bonn \\ Germany \\ Phone: +49-228-3894-0 \\ Fax: +49-228-3894-180 \\ E-mail: iza@iza.org
}

Any opinions expressed here are those of the author(s) and not those of IZA. Research published in this series may include views on policy, but the institute itself takes no institutional policy positions. The IZA research network is committed to the IZA Guiding Principles of Research Integrity.

The Institute for the Study of Labor (IZA) in Bonn is a local and virtual international research center and a place of communication between science, politics and business. IZA is an independent nonprofit organization supported by Deutsche Post Foundation. The center is associated with the University of Bonn and offers a stimulating research environment through its international network, workshops and conferences, data service, project support, research visits and doctoral program. IZA engages in (i) original and internationally competitive research in all fields of labor economics, (ii) development of policy concepts, and (iii) dissemination of research results and concepts to the interested public.

IZA Discussion Papers often represent preliminary work and are circulated to encourage discussion. Citation of such a paper should account for its provisional character. A revised version may be available directly from the author. 


\begin{abstract}

\section{Permanent Jobs, Employment Protection and Job Content}

Using Programme for the International Assessment of Adult Competencies (PIAAC) data for 21 countries, I study the impact of employment protection laws (EPL) on job content. Economic theories predict that stricter protection increases workers' willingness to make firmspecific investments. These theories also predict that stricter protection leads firms to raise their hiring and promotion standards for permanent jobs. Both of these mechanisms predict higher levels of job content in permanent than in temporary jobs; further, it is predicted that stricter EPL increases the gap in job content between permanent and temporary jobs due both to workers' investments and firm hiring standards. I found support for both sets of predictions. First, in almost all cases, workers' self-reported use of influence, reading, writing, planning, numeracy and ict skills, and their task discretion, were higher in permanent than in temporary jobs. Second, stricter EPL raised the gap in job content for influence, reading, writing and planning skills used in permanent jobs vs. temporary jobs, controlling for industry, occupation and human capital. This finding suggests that workers are making firm-specific (or perhaps occupation- or industry- specific) investments that raise their productivity levels and thus warrant higher level job content. These effects became larger when I did not control for industry, occupation, government employment, and human capital variables including schooling, actual labor market experience, cognitive test scores and nativity status. The larger effects of EPL without these controls provide some indirect support for the idea that EPL leads firms to raise their hiring standards.
\end{abstract}

JEL Classification: J31, J42

Keywords: job content, skills, permanent employment, employment protection laws, temporary jobs

Corresponding author:

Lawrence M. Kahn

Cornell University

258 Ives Hall

Ithaca, New York 14583

USA

E-mail: Imk12@cornell.edu

\footnotetext{
${ }^{*}$ Preliminary draft. Comments welcome. The author thanks Eric Hanushek for advice about the PIAAC database and additional country data.
} 


\section{Introduction}

Over the last three decades, economists have devoted considerable attention to studying the impact of employment protection laws (EPL) on a variety of labor market and macroeconomic outcomes. These include overall unemployment, productivity, labor market dynamism, labor market segmentation, and wage inequality. Laws making it expensive or administratively cumbersome to fire workers have been said to reduce incentives for job creation, possibly leading to high levels of unemployment in some European countries (OECD 2004). On the other hand, by reducing firms’ incentive to lay workers off, such laws may deter one source of unemployment-job loss. The overall impact of such laws on the average level of labor demand may thus be theoretically ambiguous (Bertola 1992).

Microeconomic research on the impact of EPL has studied their effects on labor market flows as well as firm hiring decisions. By deterring hiring and firing, EPL are said to reduce labor mobility, possibly reducing overall labor productivity by deterring labor reallocation (Bentolila and Bertola 1990). On firm hiring, economists have emphasized that stronger EPL leads firms to raise their standards before hiring or promoting workers into permanent jobs (Blanchard and Landier 2002). These laws may thus increase the concentration of new entrants into temporary jobs, from which employers can fire workers with relatively little penalty (Kahn 2007).

In this paper, I study a further consequence of EPL’s impact on hiring and promotion standards for permanent jobs. Specifically, by leading firms to raise their hiring and promotion standards for entry into permanent jobs, EPL may indirectly lead firms to assign higher-level skilled tasks to these workers to a greater degree than otherwise would be the case. Such tasks include communicating with or influencing the work of other employees, and also may involve a higher level of autonomy or self-supervision than otherwise. These higher-level tasks have been emphasized in recent discussions of the polarization of the labor market, in which the demand for 
routinized, middle-level tasks has fallen relative to the higher level tasks and the nonroutine manual tasks (Acemoglu and Autor 2011).

EPL can lead firms to assign higher level tasks to their permanent workers through several mechanisms. On the one hand, EPL may lead firms to hire more skilled workers for permanent jobs than otherwise, and worker skill and higher level tasks may be complements. On the other hand, taking on higher level tasks may require the worker to make firm-specific investments. Having the employment stability that is a result of EPL may increase workers’ willingness to make such investments. In the absence of EPL, firms might not provide employment security out of concerns of adverse selection (Levine 1991) or because of difficulties in observing employees’ effort levels (MacLeod and Nakavachara 2007).

In this paper, I use data from the Programme for the International Assessment of Adult Competencies (PIAAC) microdata base to study the relationships among permanent employment, temporary employment, EPL, and the task content of jobs. The PIAAC contains information on individual workers' job content, including self-reported measures of the degree to which their jobs require higher level content such as reading, writing, influencing other workers, task discretion, planning, numeracy skills, and information and computer technology skills. In addition, the data include measures of worker cognitive skills, schooling, actual labor market experience, industry and occupation, permitting a detailed control for measured worker ability. Moreover, the data include information on the type of employment contract one has, specifically, whether it is a temporary or a permanent contract. A key implication of economic theories of permanent employment is that workers on permanent jobs will be given higher level tasks than those on temporary jobs. Moreover, this gap should be wider the more strict employment protection mandates are, due to the higher promotion/hiring standards into permanent jobs that such mandates cause.

These predictions are borne out in the PIAAC data. First, in virtually every country, those on permanent jobs perform considerably higher level tasks than those on temporary jobs, even after controlling for cognitive skills, nativity, experience, schooling, industry and 
occupation. Second, a country's unexplained gap in the incidence of such tasks between permanent and temporary jobs is significantly positively related to the OECD's measure of employment protection strictness, even controlling for other national institutions such as collective bargaining coverage and product market regulation. Thus, EPL may accelerate the polarization of the labor market both by increasing the demand for higher level job tasks and by creating a larger gap than otherwise between the job content of permanent and temporary jobs.

\section{Previous Research on the Impact of Employment Protection on Productivity and This Paper's Contribution}

Previous research on the impact of EPL on productivity has emphasized several routes through which these laws can affect firm performance. First, some have argued that because employment protection can discourage both job destruction and job creation, EPL reduces labor market dynamism (Micco and Pagés 2006). This effect has been found to reduce productivity growth, as EPL hinders the labor market’s adjustment to changing relative demands and

supplies. Specifically, Bassanini, Nunziata and Venn (2009) studied an international panel of industries from 1982-2003 for 16 OECD countries and found that EPL reduced both total factor productivity growth and total labor productivity growth in volatile industries-those with high US layoff rates, where EPL is expected to be binding.

Second, some have studied the impact of EPL on productivity levels, an outcome related to but distinct from growth in productivity. For example, EPL has the potential to raise labor costs. This outcome can occur if EPL involves some wasted expenses (from the point of view of workers and firms) on compliance costs such as legal fees and administrative costs. However, where EPL involves mandated severance pay, it is possible that wages will adjust downward to fully compensate for the costs EPL imposes (Lazear 1990). But if wages aren’t free to fully adjust, then EPL can in principle raise labor costs even where it only mandates severance pay (Belot, Boone and van Ours 2007). In this case, we expect substitution of capital for labor in the 
long run. Labor productivity would rise but total factor productivity would fall, since firms would have chosen less efficient production techniques as a result of the rise in labor costs. Autor, Kerr and Kugler (2007) test these predictions across US states where different states provide differing rights for workers to sue for wrongful discharge. In a panel of states, where such rights were enacted at different times, Autor, Kerr and Kugler (2007) find support for both of these predictions. Having the right to sue for wrongful discharge leads to higher labor productivity but lower total factor productivity.

While the research just mentioned that studies productivity growth or levels suggests that EPL may lead to efficiency losses, there is another strand of research that implies a role for EPL in alleviating some information-based market failures. Economists following this line of reasoning have suggested that in the typical workplace, efficiency can be enhanced if employees make firm-specific investments. However, since such investments may not be observable, it may not be possible to write contracts rewarding workers for making them. Moreover, if workers don't have job security, they may be reluctant to make investments since they will be lost upon discharge from the firm (MacLeod and Nakavachara 2007). While firms in these circumstances may have an incentive to offer job security even without EPL, there are several reasons why the voluntary level of security may be inefficient. First, if one firm offers job security, it is likely to attract the workers who would anticipate the highest probability of being fired in the absence of job security. This kind of adverse selection could deter firms from offering job security, and EPL could under these circumstances be efficiency-enhancing (Levine 1991). Second, a firm might not be able to credibly offer an assurance of only just cause dismissals because workers can’t verify which dismissals may be justified and which ones might not (MacLeod and Nakavachara 2007). Mandated protection against unjust dismissals can therefore have allocative effects and could enhance labor market efficiency. Third, as noted earlier, if wages can't adjust downward, then a firm might be deterred from offering as full a promise of job security as would be optimal from a social point of view (Belot, Boone and van Ours 2007). 
MacLeod and Nakavachara (2007) reason that worker investments in firm-specific skills are more likely to occur in more highly skilled occupations than in less-skilled jobs. The authors use the variation across US states in the right to sue over unjust cause dismissals to conclude that these rights raise firms' use of technologies using higher-skilled workers. This result provides some indirect support for the reasoning outlined above.

This paper's framework is in the same spirit as the research just described in which EPL is predicted to or found to change firms' production techniques. Specifically, I use recentlycollected PIAAC data on individuals from 21 countries to study the impact of EPL on job content. The PIAAC collected information on characteristics of individuals' jobs such as the degree to which they influence others' work, the degree of autonomy they have, and their use of planning, reading, writing, mathematics and information and computer technology. These aspects of job content are very likely to be positively correlated with the kind of firm-specific investments emphasized in the literature on EPL. Much of the economic literature on job content assigns the occupational averages of job tasks to individuals based on the occupation they report (e.g. Autor and Acemoglu 2011). In contrast, the PIAAC contains information on individuals' own job content and thus may suffer less from errors than using occupational averages would entail, subject of course to individuals' errors in reporting their job content. The PIAAC also collected detailed information on workers’ cognitive skills and actual labor market experience, two important measures of worker skills that most data sets have no information on. Moreover, I note that in OECD countries permanent and temporary jobs usually differ greatly in the degree to which workers have job security. Thus, within a country, it may be useful to compare the job content of permanent and temporary jobs, and the research above implies that those on permanent jobs will engage in the types of tasks just mentioned to a greater degree than those on temporary jobs, other things equal. Further, as discussed below, the gap between the job content of permanent and that of temporary jobs is expected to be greater the more strict EPL is with respect to permanent employment. 
The literature on the impact of EPL, hiring standards, and firm-specific investments suggests several routes through which EPL can affect job content. First, MacLeod and Nakavachara's (2007) model implies that for a given worker in a given industry and occupation, greater employment protection will lead to more firm-specific investments by that worker. This prediction implies that the EPL will raise the gap in job content between permanent (i.e. protected) and temporary jobs (i.e. less protected) controlling for individual worker skills, industry and occupation. Second, to the extent that EPL raises labor costs, it can be expected to affect the industry-occupation mix of a country, since some industries and occupations are likely to be more prone to dismissals in the absence of EPL than others. This reasoning implies that the full effects of EPL on observed job content will not be accounted for if one controls for industry and occupation. Third, Blanchard and Landier's (2002) model of hiring and promotion standards implies that EPL will raise the standards firms will use in granting permanent employment status. These higher productivity individuals will be likely to be given higher level tasks. For example, workers who are more literate are likely to be more productive on tasks that involve writing reports and communicating with others than workers who are less literate. This model implies that controlling for worker human capital characteristics such as schooling, experience and cognitive ability may also understate the full impact of EPL on the relative levels of job content in permanent vs. temporary jobs and thus dualism in the labor market. One can potentially gain insight on these routes of impact of EPL on job content by comparing empirical models that control for industry, occupation, and human capital characteristics and ones that don't. In the empirical work described below, I conduct such a comparison.

\section{The PIAAC Database}

I use the PIAAC microdata base to study the impact of EPL on job content. The data collection was supervised by the OECD; the surveys were conducted from August 2011 to 
March 2012 and cover a cross-section of 24 countries. ${ }^{1}$ Of these, I am able to use 21 countries which have data available on key explanatory and dependent variables: Australia, Austria, Belgium, Britain, Czech Republic, Denmark, Estonia, Finland, France, Ireland, Italy, Japan, Korea, Netherlands, Norway, Poland, Russia, Slovak Republic, Spain, Sweden, and the USA. The PIAAC is distinctive for having detailed measures of cognitive ability that come from tests that allow international comparisons. Cognitive ability in three areas is measured: i) Literacy; ii) Numeracy; iii) Problem-solving in technology-rich environments. The OECD used Item Response Theory to construct plausible values for each of these types of cognitive ability measures based on respondents’ answers to questions (OECD 2013b, Chapter 17). ${ }^{2}$

In addition, the database includes self-reported measures of the following relevant aspects of job content: i) influence over others at work; ii) task discretion; iii) use of reading at work; iv) use of writing at work; v) extent of planning at work; vi) use of numeracy skills at work; vii) use of information and computer technology skills at work. These measures were created by the OECD based on individuals' answers to questions about job content and are scaled so that the overall sample mean across countries is 2.0 and variance is 1.0 (OECD 2013a, p. 143). The types of activities and skills that make up these categories of job content are listed in Table 1.

One concern about the international data is that there may be country-specific differences in the way people take tests or respond to questions about job content. To some degree the effects of these possible differences will be alleviated by comparing permanent and temporary jobs within each country. In addition to the data on job content, the PIAAC collected information on one's type of employment contract—i.e., temporary or permanent. In my basic analyses, I keep only those with permanent or fixed term contracts, thus deleting observations for apprentices, those working for a temporary work agency and those with no contract. However,

\footnotetext{
${ }^{1}$ For further description of the PIAAC data, see OECD (2013a, b and c) and Hanushek, Schwerdt, Wiederhold, and Woessmann (2015).

2 The OECD produced 10 plausible values for each cognitive skill, and I use the first plausible value in each case, following Hanushek, Schwerdt, Wiederhold, and Woessmann (2015).
} 
when I included those working for a temporary work agency and coded them as having temporary jobs, the results were very similar.

In addition to the basic cognitive skill and job content information, the PIAAC measures actual labor market experience, unlike most publicly-available, nationally-representative data bases. This variable has been found to be especially important in understanding gender differences in labor market outcomes, since women tend to have more interrupted careers than men do (Mincer and Polachek 1974; O’Neill and Polachek 1993; Blau and Kahn 1997). The PIAAC also has basic demographic information such as age, nativity, gender and schooling, as well as a set of indicators for government employment, occupation and industry. For each country, I include measures of EPL strictness, collective bargaining coverage, and entry regulation, which I take from the data assembled by Hanushek, Schwerdt, Wiederhold and Woessmann (2015) and from Venn (2009). My main focus will be on the impact of EPL on the difference in job content between those in permanent jobs and those on temporary jobs.

\section{Sample Characteristics of the PIAAC}

Table 2 contains mean values of key job content and explanatory variables displayed separately by employment contract type. The Table aggregates the 21 countries and uses adjusted sampling weights in which each country is given equal weight. Appendix Tables A1 and A2 show data separately by country. The PIAAC restricts the sample to ages $16-65$, and I use that restriction in this paper. In Table 2, I first show descriptive statistics for men and women pooled and then separately by gender. Job content variables include the use of reading, writing, numeracy or information technology skills, as well as the level of influence on other people's work, the degree of task discretion, the use of planning, the use of numeracy skills, and the use of information and computer technology skills. In each case, permanent jobs exhibit higher levels of these skills and tasks on average than temporary jobs, in line with the reasoning about firing costs discussed above. The average gap in these skills and tasks between permanent 
and temporary jobs ranges from 0.0689 (influence) to 0.1891 (task discretion) standard deviation units. $^{3}$

To assess the magnitude of these differences, I use log hourly earnings regressions to attach dollar values to differences in job content. The purpose of the regressions isn't to estimate a causal relationship between exogenously changing job content and an individual's wages. Rather, the goal is to translate differences in job content into job value differences. These value differences could come about either due to additional training needed to do a job with, for example, one standard deviation more task autonomy. Alternatively, the value differences could be caused by higher hiring standards necessitated by increasing the task autonomy of a job. I estimated regressions pooled by gender and country of log hourly earnings (in U.S. purchasingpower-parity currency units) of the following form:

(1) $\ln \mathrm{w}_{\mathrm{a}} \mathrm{a}_{0}+\mathrm{a}_{1}$ female + a influence + asreading $+\mathrm{a}_{4}$ writing $+\mathrm{a}_{5}($ task autonomy $)$ $+a_{6}$ planning + a 7 numeracy + asict $+d_{j}+B^{\prime} X+u$,

where for each individual in country $\mathrm{j}$, w is hourly earnings, female is a female dummy variable, influence-ict are the individual's job content measures for influence, reading, writing, task autonomy, planning, numeracy and information and computer technology skills respectively, $\mathrm{d}_{\mathrm{j}}$ is a country effect, $\mathrm{X}$ is a vector of controls, and $\mathrm{u}$ is a disturbance term. ${ }^{4}$

In equation (1), the $\mathrm{X}$ vector includes years of schooling, actual labor market experience and its square, numeracy and literacy test scores, and an immigrant dummy. Thus, equation (1) in effect computes prices of job content variables controlling for measured human capital and demographic characteristics. I also estimated (1) excluding the X variables. By excluding X, we can assess the gross value differences associated with different jobs, part of which may come about through the hiring of better-qualified workers. I don’t control for industry and occupation

\footnotetext{
${ }^{3}$ Recall that the job content variables have been scaled to have variance equal to 1.0 .

${ }^{4}$ In the analysis of wages, I only keep observations with hourly earnings greater than or equal to $\$ 2$ and less than or equal to $\$ 500$.
} 
in (1) because, for example, increasing from minimal to maximal use of information and computer technology skills is likely to entail a different occupation and possibly even a different industry. Finally, in (1) I cluster the standard errors by country.

The results of the wage regressions are shown in Appendix Table A3. When I don't control for human capital variables and the immigration indicator, the wage coefficients of the job content variables are all positive, with four of the seven highly statistically significant (influence, reading, task discretion, and ict). Controlling for human capital and immigration status, the effects are positive six of seven times, with a small and insignificantly negative planning coefficient. Four of the six positive coefficients remain significant. However, controlling for human capital and immigration status leads to generally smaller coefficients, suggesting that when a firm increases the skill of its jobs, it hires more skilled workers as well. Schooling, experience, numeracy test score, literacy test score and being male all, not surprisingly, are associated with higher wages.

I now use the wage regression coefficients in Appendix Table A3 to assess the differences in the value of permanent and temporary jobs based on their differences in job content. To accomplish this, I compute the following sum:

(2) $b_{2}\left(\right.$ influence $_{\mathrm{p}}$-influence $\left.\mathrm{t}\right)+\mathrm{b}_{3}\left(\right.$ reading $_{\mathrm{p}}$-reading $\left.\mathrm{t}\right)+\mathrm{b}_{4}\left(\right.$ writing $_{\mathrm{p}}$-writing $\left.\mathrm{t}\right)+$ $\mathrm{b}_{5}\left(\right.$ task autonomy $\mathrm{p}_{\mathrm{p}}$-task autonomy $)+\mathrm{b}_{6}\left(\right.$ planning $_{\mathrm{p}}-$ planning $\left._{\mathrm{t}}\right)+\mathrm{b}_{7}\left(\right.$ numeracy $_{\mathrm{p}}$-numeracyt $)$ $+\mathrm{b}_{8}\left(\right.$ ict $\left._{\mathrm{p}}-\mathrm{ict} \mathrm{t}\right)$

where $b_{2}-b_{8}$ are respectively the estimated values of $a_{2}-a_{8}$ and $p$ and $t$ subscripts signify the sample mean of the indicated job content variables for permanent and temporary jobs respectively.

Computing expression (2) for the two specifications of the wage regression, I find that on average in the PIAAC sample, the differences in job content between permanent and temporary jobs are associated with 0.0207 log points higher wages controlling for human capital and immigration status and 0.0353 log points not controlling for these factors, and both of these 
effects are statistically significant at much better than the $1 \%$ level. Thus, higher level jobs are indeed associated with more favorable human capital characteristics. Of course, permanent jobs typically have a much longer duration than temporary jobs, so these hourly earnings differences will become magnified over time into larger income differences.

Looking at the other differences between worker characteristics on permanent vs. temporary jobs, we see that years of schooling are comparable. However, permanent jobs are less likely to be staffed by immigrants than temporary jobs are. Moreover, workers on permanent jobs have on average 5.2 years' more actual experience than workers on temporary jobs, and temporary jobs are disproportionately staffed by women. Similar demographic differences have been found in earlier work on temporary vs. permanent employment (Kahn 2007). ${ }^{5}$ Workers on permanent jobs have slightly higher numeracy and literacy test scores than workers on temporary jobs; however, the reverse is true for problem-solving skills. Moreover, permanent jobs are disproportionately in managerial, professional and technical occupations, while temporary jobs are more likely to be found in clerical/sales/service or blue collar occupations. Overall, then, permanent jobs are higher-level than temporary jobs.

These patterns are qualitatively similar when the sample is stratified by gender, as shown in Table 2. However, there is a larger gap in job content and skills between permanent and temporary jobs among men than among women. For example, the gap for men is larger in each of the job content variables than for women except for use of numeracy skills, where the permanent-temporary gap is about 0.14 standard deviations for men and for women. Further, among men, workers on permanent jobs have about 0.13 more years of schooling than those on temporary jobs, while among women, temporary workers actually have 0.21 more years of schooling. And test scores are higher for permanent than temporary workers among men; however, among women, temporary workers have slightly higher literacy and problem solving skills than permanent workers. Moreover, while among women, permanent workers have higher numeracy scores than temporary workers, the gap is larger for men. It is possible that these

\footnotetext{
${ }^{5}$ Kahn's (2007) data didn't have information on experience but did have age data.
} 
gender differences reflect the fact that the temporary workers are younger, and women's education has been rising relative to men's across the OECD (Goldin, Katz and Kuziemko 2006).

As noted, Appendix Tables A1 and A2 show information on job content and worker characteristics separately by country. The patterns are similar to those in Table 1 with two important exceptions: Australia and the United States. In contrast to virtually all of the other 19 countries for which we have complete data, in the United States and Australia, temporary jobs involve more reading, writing, and influence on others than permanent jobs; and temporary jobs in the United States call for more planning than permanent jobs do. Moreover, temporary workers in the United States and Australia have more education, higher test scores, and are more likely to be in professional or technical positions than permanent workers, again in contrast to almost all of the other countries; again in contrast to the other countries, temporary workers in the United States have more work experience than those on permanent jobs.

Part of these differences between the United States and Australia on the one hand and the other countries may stem from the fact the United States has the weakest employment protection on permanent jobs, and Australia has the fourth weakest employment protection levels in our sample, making permanent jobs them less secure than in the other countries. In addition, the flexibility of the U.S. labor market—i.e., its relative lack of regulation—allows even high level jobs to be designed on a temporary basis. Workers may be willing to take such jobs in return for a chance to be hired into regular positions after having been screened in temporary jobs. For example, Kalleberg, Reynolds and Marsden (2003) surveyed U.S. organizations that used employment intermediaries and found that the most common stated reason for using such staffing methods was that the temporary workers supplied "special skills." $64 \%$ of firms mentioned skills as a reason for using intermediaries. Moreover, while temporary employment in the United States was traditionally associated with lower level jobs such as clerical work, in

\footnotetext{
${ }^{6}$ While employees of temporary help agencies (an example of an employment intermediary) might be considered permanent workers, I infer that use of an intermediary is qualitatively similar to hiring someone on a temporary basis.
} 
the 1990s, the share that was highly skilled rose relatively and absolutely (Kunda, Barley and Evans 2002).

In the Australian case, Louie, et. al (2006) note that workers on fixed term contracts have higher level jobs and higher levels of education than workers on permanent jobs, similar to the findings shown in Tables A1 and A2. The authors suggest that recent lessening of labor market regulations in Australia may have contributed to these outcomes. Because of their differing profiles with regard to temporary employment relative to the other countries in the sample, I conducted analyses of job content both including and excluding the United States and Australia.

Figures 1-7 show univariate relationships between a country’s difference in job content between permanent and temporary jobs and the OECD’s measure of employment protection strictness. In the cases of influence on others, writing, reading, task discretion, and planning, a higher gap was significantly positively associated with stricter employment regulation whether or not the United States and Australia are included in the sample. However, use of numeracy skills and information technology work did not fit this pattern. There was no relationship between EPL and the permanent-temporary gap in the use of numeracy skills, and a negative relationship between EPL and the gap in information and computer technology skills, a relatively specialized job characteristic. It is likely that reading, writing, task discretion, planning and influencing others are traits that are potentially present in all jobs, and the pattern in Figures 1-5 does suggest that EPL raises the relative complexity of permanent vs temporary jobs. Of course, the Figures don't control for other influences on job content, and in the next section, I outline the methodology I use to accomplish this.

\section{Empirical Procedures and Results}

The basic research design used here is to assess the influence of EPL on the gap in job content between permanent and temporary jobs, controlling for other influences. The simplest 
analysis I implemented involved estimating separate regressions for each job content variable with the data pooled across country and gender:

(3) $y=f(p e r m$, perm*EPL, perm*CBCOV, perm*PRODREG, Z, e)

where for each individual, y is one of the job content variables (influence, reading, writing, task discretion, planning, numeracy, ict), perm is a dummy variable equaling one for those in permanent jobs, EPL is the country's employment protection strictness measure, CBCOV is the country's collective bargaining coverage rate (fraction of workers covered), PRODREG is the OECD index of product market regulation with higher values signifying more regulation, $\mathrm{Z}$ is a vector of controls, and e is a disturbance term.

The perm*EPL coefficient will test the hypothesis that EPL widens the gap in job content between permanent and temporary jobs, controlling for the effects of two potentially important institutional determinants of job content: collective bargaining coverage and product market regulation. Collective bargaining can affect job security as well as labor costs and thus production technique. Product market regulation can also affect job security through protection against new entrants. Recall MacLeod and Nakavachara’s (2007) model in which greater job security increased workers' investments in firm specific skills. Collective bargaining and product market regulation can thus have direct effects on job content through this mechanism, and it is plausible that the impact would not be the same for those on permanent jobs as it would be for those on temporary jobs. For example, collective bargaining is more likely to cover those in permanent jobs than in temporary employment, and product market regulation may have smaller effects on the job security of those already in protected jobs than among those on temporary jobs. On the other hand, since EPL may affect the degree of collective bargaining and even perhaps the degree of product market regulation, I also report models including only the EPL-permanent interactions. 
As discussed above, I implement several alternative models where the control variables in $\mathrm{Z}$ are allowed to vary. First, I include the following controls in Z: a female dummy variable, years of schooling, years of actual labor market experience and its square, an immigrant dummy variable, numeracy test score, literacy test score, a government employment indicator, industry and occupation dummy variables, and country dummy variables. ${ }^{7}$ Note that the inclusion of country dummy variables fully absorbs the main effects of employment protection, collective bargaining coverage, and product market regulation. I estimate $\mathrm{f}(-)$ as a linear regression and cluster the standard errors at the country level. The Z variables include some measures of skills such as schooling, experience, test scores and nativity, which may also be a proxy for discrimination. In addition, the controls for industry and occupation adjust for exogenous factors that could affect job content, since, for example, professional and technical jobs are likely to have higher level cognitive content than manual occupations.

Second, as noted, employment protection may affect the industrial and occupational mix by altering labor and other costs differentially across sectors and occupations. Thus, I also estimate (3) by excluding the industry and occupation dummies and the government dummy. Third, because EPL is likely to affect hiring standards, I further estimate a version of (3) excluding the human capital and immigrant variables (schooling, experience, test scores, and the immigrant dummy variable). ${ }^{8}$ In addition, because of the seemingly idiosyncratic patterns in the United States described earlier, I also estimate equation (3) excluding the United States. And because the female labor market may differ from the male labor market in occupations and reward structures, I also estimate (3) separately by gender.

While pooling country (and gender) gives the largest sample size, equation (3) forces the effect of each variable to be the same for each country other than the perm-interactions which of

\footnotetext{
${ }^{7}$ As noted, the PIAAC also conducted tests of problem-solving ability. However, because these were administered to far fewer people than the numeracy and literacy tests, I don't use the problem solving test score in my main analyses. But when I re-estimated the basic models including problem solving, the results were very similar to those presented in the paper.

${ }^{8}$ I include the gender dummy variable to account for compositional differences in the labor force, although the results were not affected by excluding this variable as well.
} 
course allow the impact of permanent employment to differ according to the country's policies and institutions. Thus, at the expense of losing many degrees of freedom, I also estimated (3) separately by country (and by country-gender group) where of course the country dummies are omitted and so are the perm-interactions. These disaggregated equations then give for each country (or country-gender group) its own effect of permanent employment on job content. I then regress these coefficients on EPL, CBCOV, and PRODREG in models that include 21 observations. I estimate these models unweighted where the standard errors are heteroscedasticity-robust. In addition, I also estimate weighted regressions, where I weight each observation by the inverse of the standard error of its perm coefficient.

Tables 3-5 show results for the interaction between permanent employment and EPL in the models pooled across countries, including the United States and Australia (results excluding the United States and Australia are discussed below). As mentioned earlier, I estimate models with alternative sets of controls. Table 3 includes the full set of human capital, occupation and industry variables, in effect estimating the direct impact of EPL on job content. Table 4 shows results not controlling for industry and occupation, allowing EPL to affect these intermediate variables. And Table 5 further excludes the human capital variables, allowing EPL to affect hiring and promotion standards. In addition, the Tables show results where EPL is the only institution interacted with permanent employment and also results where I additionally include interactions between permanent employment and collective bargaining and product regulation. Tables 3-5 show results with men and women pooled (with a gender dummy variable) and also separately by gender. Appendix Table A4 shows the full regression results for the fullyspecified model pooled by gender (summarized in Table 3A), except for not reporting the country dummy variable coefficients to conserve space.

Looking at the models pooled by gender and country, we see that Tables 3-5 show strong, significantly positive effects of EPL on the use of influence, reading, writing and planning skills in permanent relative to temporary jobs in all specifications. These results hold up whether or I control for permanent employment interactions with collective bargaining coverage and product 
market regulation. In addition, when I control for these two interactions and the full set of controls (Table 3A), EPL is also seen to significantly increase the relative use of numeracy skills in permanent jobs. The coefficients for influence, reading, writing, and planning skills all become larger in magnitude when I exclude industry and occupation (Table 4) and further exclude the human capital variables (Table 5), suggesting that EPL affects the allocation of labor resources across sectors and also hiring standards. In other words, Tables 3-5 show for the samples pooled by gender that not only does EPL lead to higher level job content along these dimensions for workers of a given measured skill level, industry and occupation; EPL also leads to the relative expansion of industries and occupations that use higher level job content and the relative hiring of more highly skilled workers in permanent jobs, who then have higher level job content than otherwise.

Tables 3-5 do not show strong results for the use of numeracy skills or information and computer technology skills (ict). While EPL is found to significantly positively interact with permanent employment in affecting the use of numeracy skills in the pooled sample with the full set of controls (Table 3A), this finding becomes smaller and insignificant when I don't control for industry, occupation, government employment, and human capital (Tables 4A and 5A). And the effects of EPL on the permanent-temporary gap in the use of ict skills are usually negative, sometimes significantly so and other times not significant. As mentioned earlier, numeracy and ict skills may be relatively specialized to particular sectors of the economy, while reading, writing, influencing others, planning, and task discretion are aspects of jobs that are likely to affect all sectors. Thus it may not be surprising that the effects on these more widely-used skills are stronger.

To assess the magnitudes of the effects of EPL, I use the coefficients on each skill in wage equations as discussed earlier. As mentioned, these wage equations give an estimate of the increase in the value of a job associated with a one standard deviation increase in the use of the indicated skill. Using this approach, I evaluated the effects in the gender-pooled models in Tables 3-5 for an experiment in which we increase the EPL measure from its minimum value of 
1.1714 (United States) to its maximum value of 3.0833 (Belgium). Table 6 shows that the wage value of these effects in the full set of 21 countries ranges from 0.0102 to 0.0653 log points not controlling for permanent employment-collective bargaining coverage and product market regulation interactions and from 0.0187 to $0.1075 \log$ points controlling for these interactions. Moreover, the magnitudes are similar whether or not I control for industry and occupation; however, the wage effects become substantially larger when I don’t control for human capital in the job content equations. Specifically, comparing the third row of Table 6 with the first two rows implies that EPL has an important effect on job content through changing firms’ hiring decisions with respect to schooling, experience, cognitive test scores or nativity status. But the first row of Table 6 and the significantly positive effects in Table 3 for influence, reading, writing and planning skills imply that EPL also leads to higher level job content even in the same industry and occupation, controlling for worker skills.

Tables 3-5 also show results for the impact of EPL on job content disaggregated by gender. Overall, the findings are stronger for men, with significantly positive effects of EPL on the relative use of influence, reading, writing, and planning skills in permanent jobs. Moreover, there is some evidence of positive effects on the use of numeracy skills for men as well (Tables 3B and 5B). For women, there are significantly positive effects in all three specifications for reading, writing and planning skills, with some evidence of positive effects on influence and task discretion. The stronger effects of EPL on men's job content than on women's job content are consistent with earlier research that found a larger permanent job wage premium for men than for women among European countries (Kahn 2016). Firms may be relatively reluctant to assign higher level tasks to women if they anticipate that women will leave the firm; alternatively, women may self-select out of such jobs, anticipating work force interruptions. ${ }^{9}$

As mentioned earlier, the United States and Australia differ from the other countries in the PIAAC data base for having relatively high level temporary jobs. This outcome may, of

\footnotetext{
9 For further discussion of the role of anticipated employment stability on gender differences in labor market outcomes, see Blau and Kahn (forthcoming).
} 
course, be a consequence of the high level of flexibility in the United States and Australian labor markets. However, there may also be other causes of such a pattern, and I have estimated the basic models excluding the United States and Australia. The results for the EPL-permanent employment interactions are shown in Appendix Table A5 for the fully-specified model, pooled by gender. The overall pattern is similar to but weaker than the results shown in Table 3A where the United States is included. There is evidence in the full specification excluding the United States and Australia that EPL raises the relative use of reading, writing, task discretion and planning skills in permanent jobs. ${ }^{10}$ And, excluding industry, occupation, the government indicator, and the human capital variables, EPL is seen to significantly raise the relative use of influence, reading, writing, and planning skills, as well as significantly increasing task discretion in permanent relative to temporary jobs (results available upon request). Moreover, as in Tables 3-5, the effects are somewhat stronger for men and than for women (results available upon request). Finally, Table 6 shows that the magnitude of the effects, measured in wage units, have the same pattern when we exclude the United States and Australia, although the effects are smaller.

Appendix Table A4 shows the basic results for the control variables in the models pooled by country and gender with the full set of controls. More educated workers, those with more labor market experience and men all have higher level job content scores, controlling for industry, occupation, government employment, test scores and nativity status. In addition, immigrants have significantly lower level jobs with respect to influence, reading, task discretion, and planning skills. However, immigrants also have significantly higher level jobs on the numeracy skill and information and computer technology dimensions. Together, the findings suggest that immigrants are more likely to be in technically-demanding jobs with lower levels of communication and responsibility than comparable natives. Moreover, scores on numeracy tests have more consistently positive effects on job content skills than scores on literacy tests, similar to the findings in the wage equations shown in Table A3. This result is also consistent with

\footnotetext{
10 The effects for task discretion shown in Table A5 are significant at the $10.7-10.8 \%$ level.
} 
Hanushek, Schwerdt, Wiederhold and Woessmann’s (2015) finding that math scores usually had a larger effect on wages than literacy scores. Further, not surprisingly, managerial, professional and technical occupations show relatively high levels of job content across the board.

The results for the other policies and institutions — collective bargaining coverage and the strength of product market regulation are somewhat fragile. For example, in models pooled by country and gender, these variables negatively interact with permanent employment in affecting reading skills (Tables 3A, 4A, and 5A), usually significantly so. The interactions for the other skills are usually not significant and sometimes change sign depending on set of included covariates (Tables 3B and $\mathrm{C}$, for example). The negative interaction effect for reading may suggest that even those in temporary jobs already have some protection either through collective bargaining or restrictions on product market entry, thus reducing the gap in job content between permanent and temporary employment.

While the results shown so far are based on regression models that pool countries, the basic findings in Tables 3-6 were very similar when I estimated separate regressions by country or country-gender group, as described above. Table 7, for example, shows the results for the impact of EPL on the country's permanent employment coefficient with the full set of controls in the first stage regressions. As in the pooled sample, EPL is seen to raise the level of job content skills used with respect to influence, reading, writing and planning. The effects remain generally stronger for men than women; and the effects become stronger when I don't control for industry and occupation, and when I also exclude these controls and the human capital variables (results available upon request). The wage weighted magnitudes of these effects were also similar to those in the pooled sample.

\section{Conclusions}

In this paper I have used PIAAC data for 21 countries to study the impact of employment protection laws (EPL) on job content. Economic theories about the impact of EPL on company 
human resource management policy predict that stricter protection will increase workers’ willingness to make firm-specific investments. Moreover, these theories also predict that stricter mandated protection will lead firms to raise their hiring and promotion standards for workers to meet in order to be placed in permanent jobs. Both of these mechanisms predict that there will be higher levels of job content in permanent than in temporary jobs; further, it is predicted that stricter EPL will increase the gap in job content between permanent and temporary jobs due both to workers' investments and firm hiring standards.

I found support for both sets of predictions. First, in almost all cases, workers' selfreported use of influence, reading, writing, planning, numeracy and ict skills, and their task discretion, were higher in permanent jobs than in temporary jobs. Second, stricter EPL was seen to raise the gap in job content for influence, reading, writing and planning skills used in permanent jobs vs. temporary jobs, controlling for industry, occupation and human capital. That is, within job type and human capital levels, EPL leads to changes in job content. This finding suggests that workers are indeed making firm-specific (or perhaps occupation- or industryspecific) investments that raise their productivity levels and thus warrant higher level job content. These effects became larger when I did not control for industry, occupation, government employment, and human capital variables including schooling, actual labor market experience, cognitive test scores and nativity status. The larger effects of EPL without these controls provides some indirect support for the idea that EPL leads firms to raise their hiring standards. Specifically, EPL leads to a higher relative levels of measured human capital in permanent jobs, leading to higher levels of the use of job content skills. These findings suggest that EPL leads to a further polarization between the permanent and temporary job sectors. In addition to of course major differences in job security and wage differences, it is possible that the effects on job content may make it more difficult for those in temporary jobs to be promoted into permanent jobs. 


\section{Appendix: Occupation and Industry Dummy Variable Categories}

\section{Occupations}

Managerial

Professional

Technical Occ.

Clerical

Sales, Serv. Occ.

Skilled Agric Occ

Craft

Operative

Elementary (the omitted category from the regressions)

\section{Industries}

Mining/Construction

Manufacturing

Transportation/Communications

Trade

Food Service and Hotels

Finance, Ins., Real Est.

Prof., Admin Svcs.

Public Admin

Education

Health

Other Svcs.

Agriculture (the omitted category from the regressions) 


\section{References}

Acemoglu, Daron and David Autor. 2011. "Skills, Tasks and Technologies: Implications for Employment and Earnings.” In Handbook of Labor Economics, Volume 4B, edited by Orley Ashenfelter and David Card (Amsterdam: Elsevier), pp. 1043-1171.

Autor, David H., William R. Kerr and Adriana D. Kugler. 2007. "Does Employment Protection Reduce Productivity? Evidence from US States.” Economic Journal 117 (521): F189F217.

Bassanini, Andrea, Luca Nunziata and Danielle Venn. 2009. “Job Protection and Productivity Growth in OECD Countries. Economic Policy 24 (58): 349-402.

Bentolila, Samuel and Giuseppe Bertola. 1990. Firing Costs and Labour Demand: How Bad is Eurosclerosis?” Review of Economic Studies 57 (3): 381-402.

Belot, Michele, Jan Boone and Jan van Ours. 2007. "Welfare-Improving Employment Protection.” Economica 74 (295): 381-396.

Bertola, Giuseppe. 1992. “Labor Turnover Costs and Average Labor Demand.” Journal of Labor Economics 10 (4): 389-411.

Blanchard, Olivier and Augustin Landier. 2002. "The Perverse Effects of Partial Labour Market Reform: Fixed-Term Contracts in France.” Economic Journal 112(480): F214-F244.

Blau, Francine D. and Lawrence M. Kahn. 1997. "Swimming Upstream: Trends in the Gender Wage Differential in the 1980s. Journal of Labor Economics 15(1, pt. 1): 1-42.

Blau, Francine D. and Lawrence M. Kahn. Forthcoming. "The Gender Wage Gap: Extent, Trends, and Explanations. Journal of Economic Literature.

Goldin, Claudia, Lawrence F. Katz, and Ilyana Kuziemko. 2006. “The Homecoming of American College Women: The Reversal of the College Gender Gap.” Journal of Economic Perspectives 20 (4): 133-56.

Hanushek, Eric A., Guido Schwerdt, Simon Wiederhold and Ludger Woessmann. 2015. "Returns to Skills Around the World: Evidence from PIAAC.” European Economic Review 74: 105-130.

Kahn, Lawrence M. 2007. “The Impact of Employment Protection Mandates on Demographic Temporary Employment Patterns: International Microeconomic Evidence.” Economic Journal 117(521): F333-F356.

Kahn, Lawrence M. 2012. “Temporary Jobs and Job Search Effort in Europe.” Labour Economics 19(1): 113-128.

Kahn, Lawrence M. 2016. “The Structure of the Permanent Job Wage Premium: Evidence from Europe.” Industrial Relations 55 (1): 149-178.

Kalleberg, Arne L., Jeremy Reynolds and Peter V. Marsden. 2003. “Externalizing Employment: Flexible Staffing Arrangements in US Organizations.” Social Science Research 32 (4): 525-552. 
Kunda, Gideon, Stephen R. Barley and James Evans. 2002. "Why Do Contractors Contract? The Experience of Highly Skilled Technical Professionals in a Contingent Labor Market.” Industrial \& Labor Relations Review 55 (2): 234-261.

Lazear, Edward P. 1990. “Job Security Provisions and Employment.” Quarterly Journal of Economics 105(3): 699-726.

Levine, David I. 1991. "Just-Cause Employment Policies in the Presence of Worker Adverse Selection.” Journal of Labor Economics 9 (3): 294-305.

Louie, Amber M., Aleck S. Ostry, Michael Quinlan, Tessa Keegel, Jean Shoveller, and Anthony D. LaMontagne. 2006. "Empirical Study of Employment Arrangements and Precariousness in Australia.” Relations Industrielles/Industrial Relations 61 (3): 465489.

MacLeod, W. Bentley and Voraprapa Nakavachara. 2007. “Can Wrongful Discharge Law Enhance Employment?” Economic Journal 117 (521): F218-F278.

Micco, Alejandro and Carmen Pagés. 2006. "The Economic Effects of Employment Protection: Evidence from International Industry-Level Data.” IZA Discussion Paper No. 2433. Bonn: IZA.

Mincer, Jacob and Solomon W. Polachek. 1974.“Family Investments in Human Capital: Earnings of Women.” Journal of Political Economy 82 (2, pt. 2): 76-108.

OECD. 2004. Employment Outlook 2004. Paris: OECD.

OECD. 2013a. OECD Skills Outlook 2013: First Results from the Survey of Adult Skills. Paris: OECD.

OECD. 2013b. Technical Report of the Survey of Adult Skills (PIAAC). Paris: OECD.

OECD. 2013c. The Survey of Adult Skills: Reader's Companion. Paris: OECD.

O’Neill, June and Solomon W. Polachek. 1993. "Why the Gender Gap in Wages Narrowed in the 1980s.” Journal of Labor Economics 11 (1, pt. 1): 205-228.

Venn, Danielle. 2009. "Legislation, Collective Bargaining and Enforcement: Updating the OECD Employment Protection Indicators.” OECD Social, Employment and Migration Working Papers, No. 89. 
Figure 1: Average Use of Influence Skills in Permanent - Average Use of Influence Skills (dinfluence) in Temporary Jobs by Employment Protection Strictness (epl)

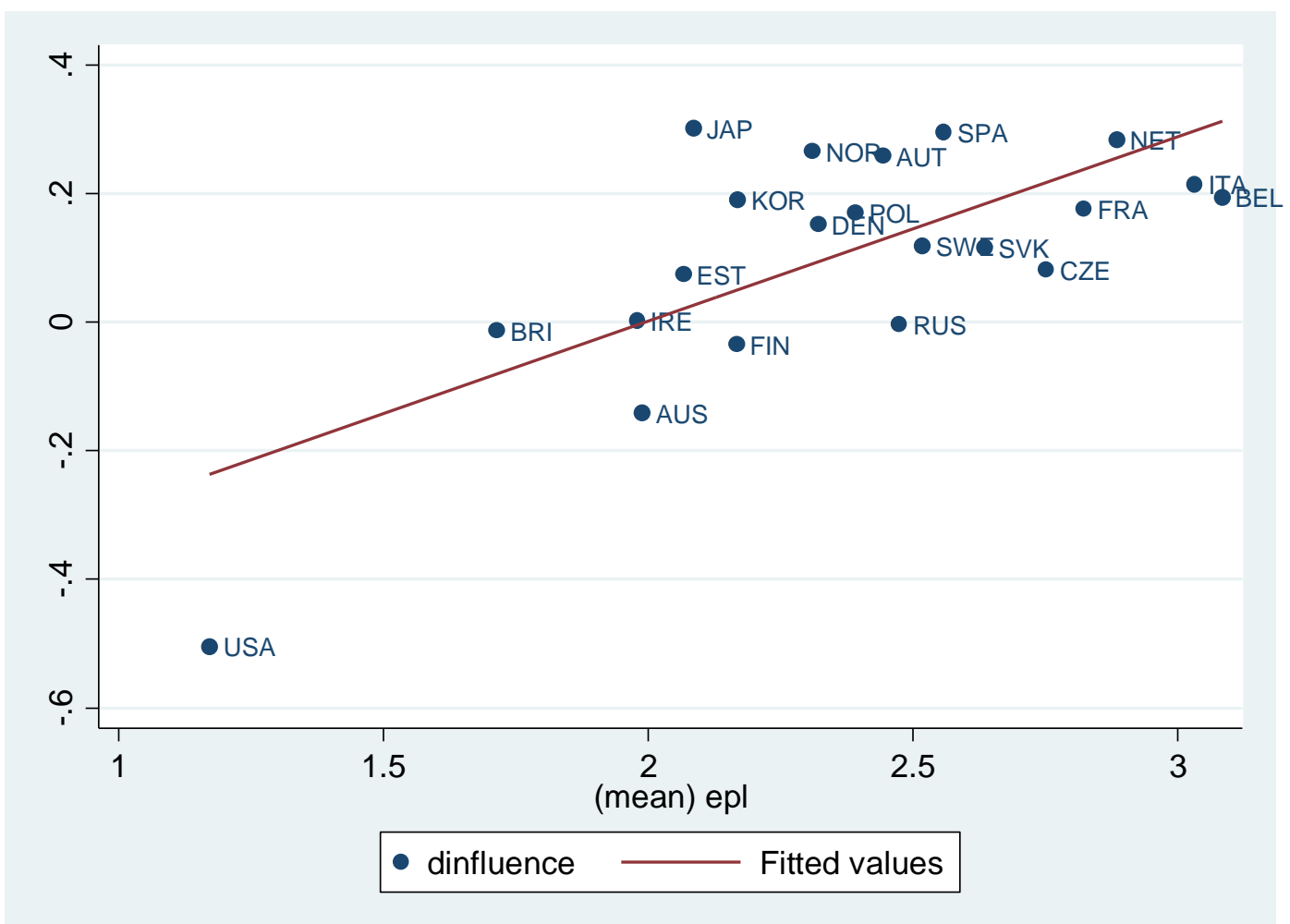

Slope of regression line is 0.2874 (robust standard error 0.0913) with USA and Australia included and 0.1229 (robust standard error 0.0535) with USA and Australia excluded. 
Figure 2: Average Use of Reading Skills in Permanent - Average Use of Reading Skills (dreadwork) in Temporary Jobs by Employment Protection Strictness (epl)

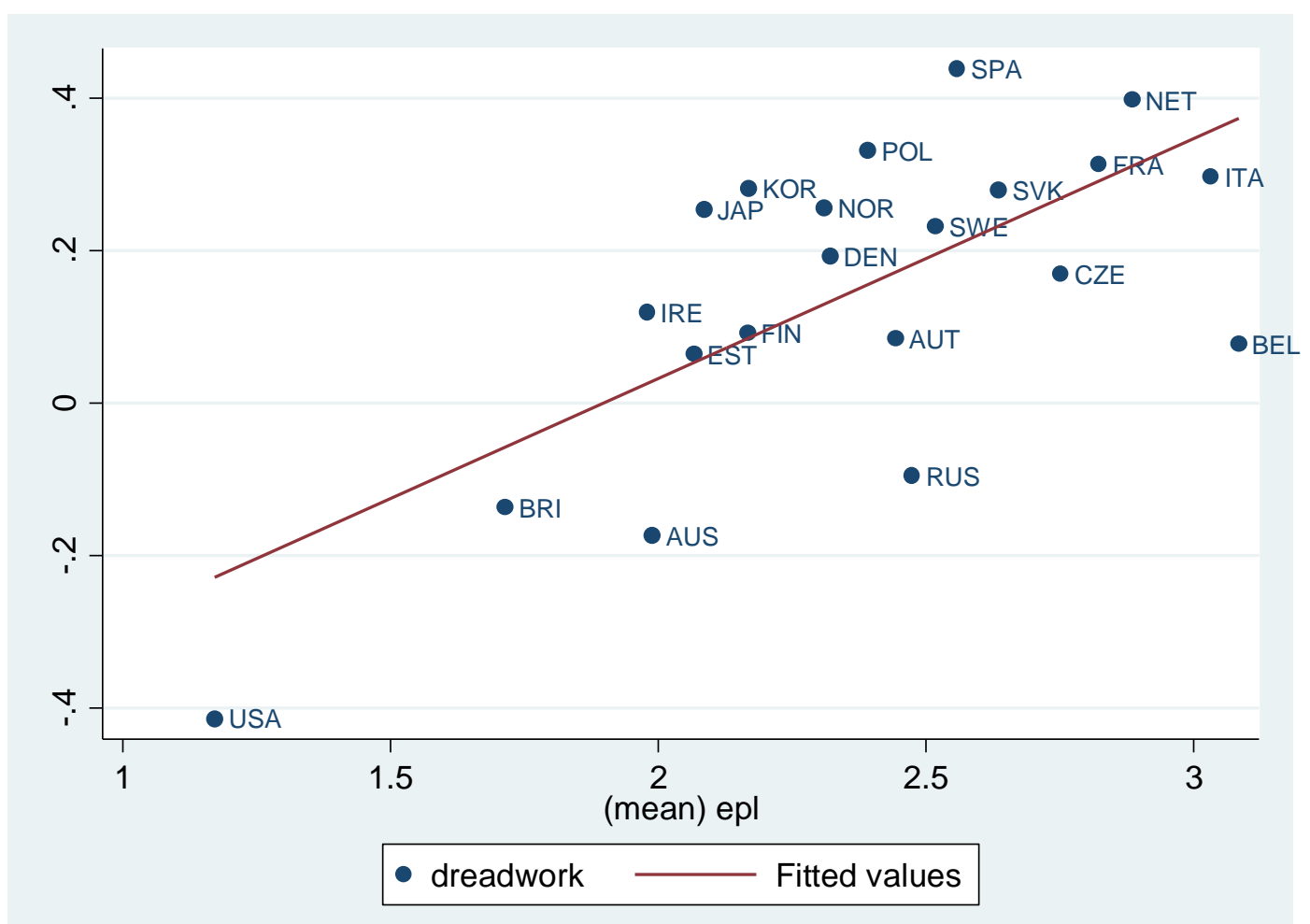

Slope of regression line is 0.3147 (robust standard error 0.0871) with USA and Australia included and 0.1812 (robust standard error 0.0982) with USA and Australia excluded. 
Figure 3: Average Use of Writing Skills in Permanent - Average Use of Writing Skills (dwritwork) in Temporary Jobs by Employment Protection Strictness (epl)

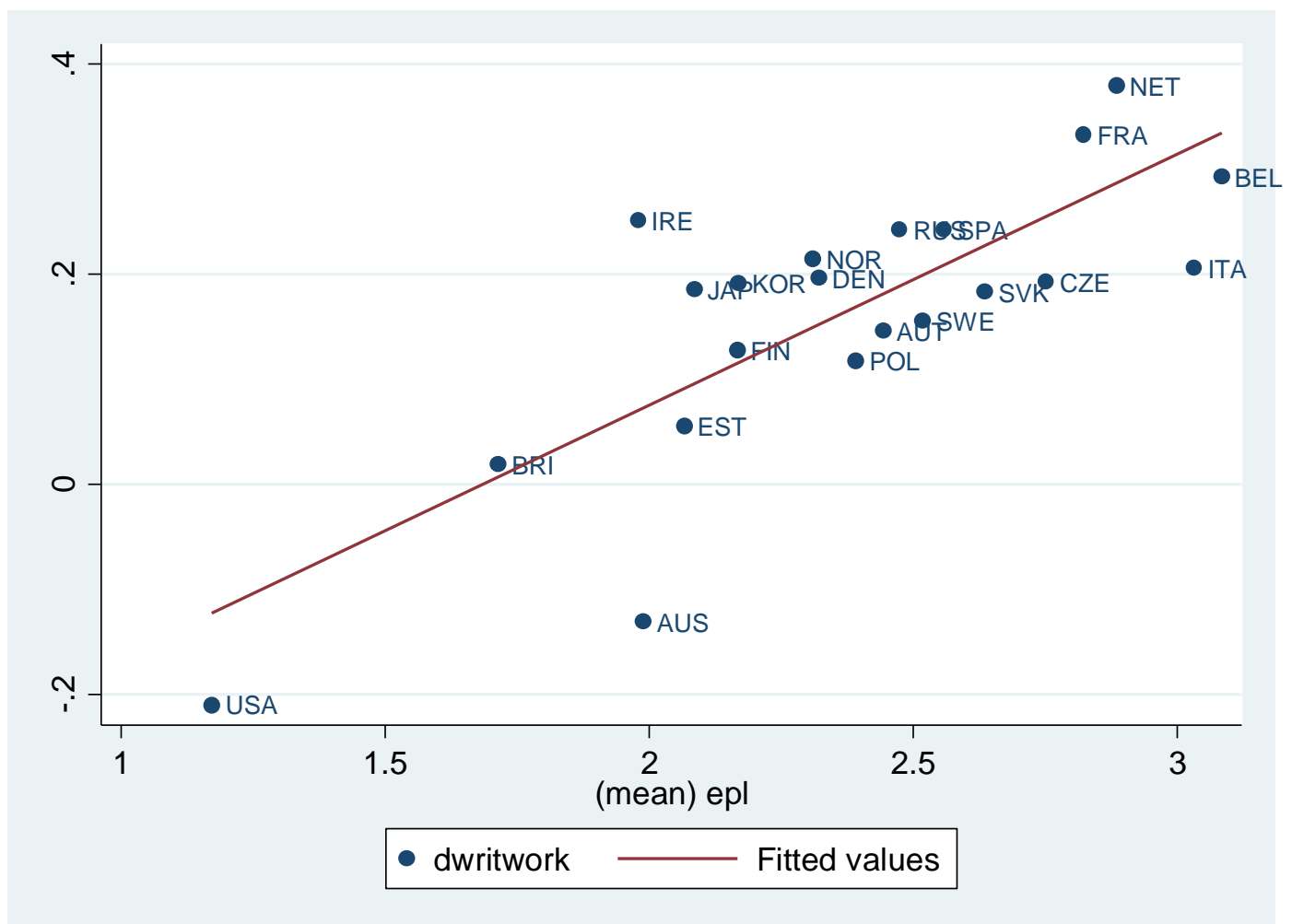

Slope of regression line is 0.2391 (robust standard error 0.0465) with USA and Australia included and 0.1561 (robust standard error 0.0495) with USA and Australia excluded. 
Figure 4: Average Level of Task Discretion in Permanent - Average Level of Task Discretion (dtaskdisc) in Temporary Jobs by Employment Protection Strictness (epl)

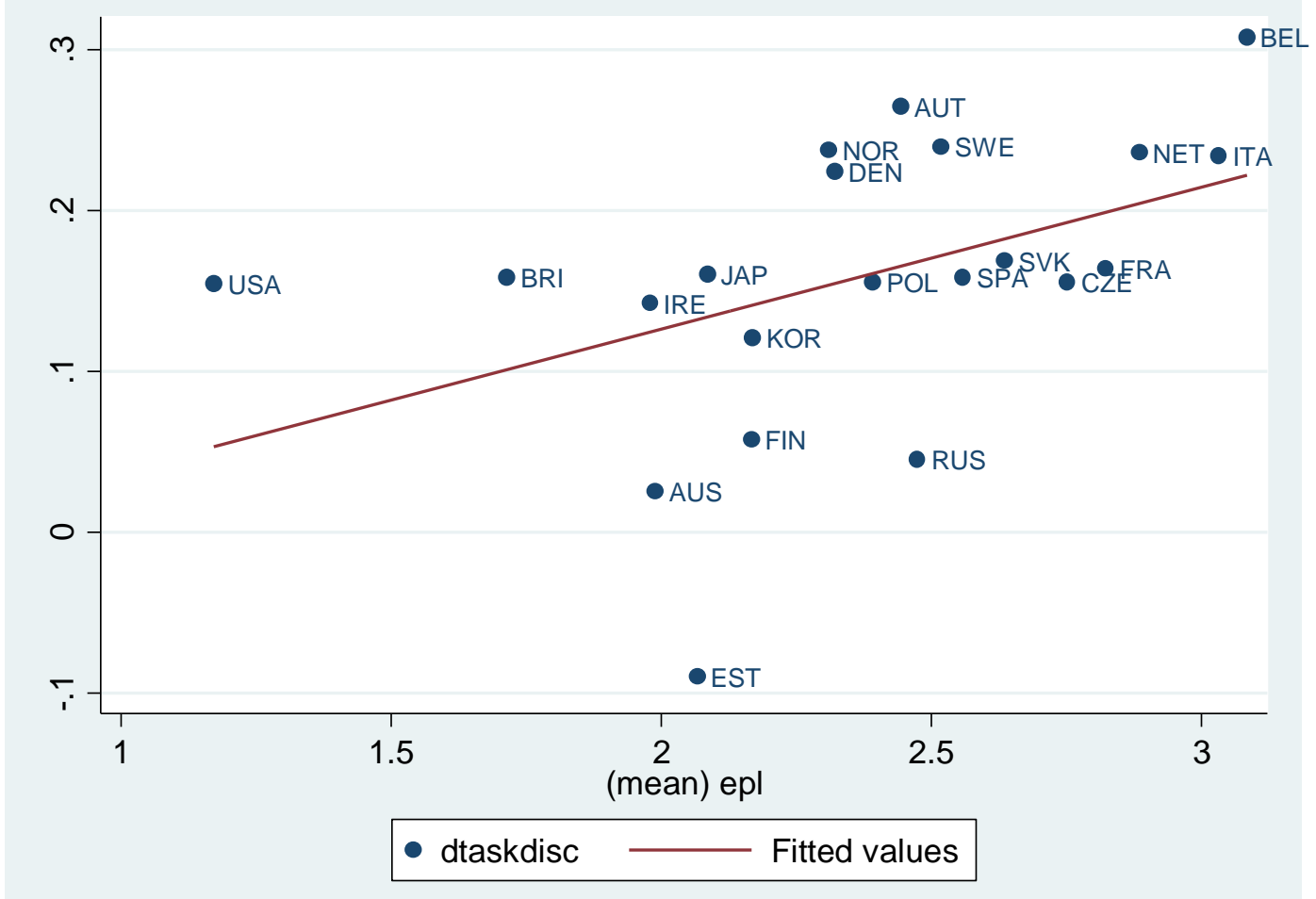

Slope of regression line is 0.0883 (robust standard error 0.0419) with USA and Australia included and 0.1223 (robust standard error 0.0495) with USA and Australia excluded. 
Figure 5: Average Use of Planning Skills in Permanent - Average Use of Planning Skills (dplanning) in Temporary Jobs by Employment Protection Strictness (epl)

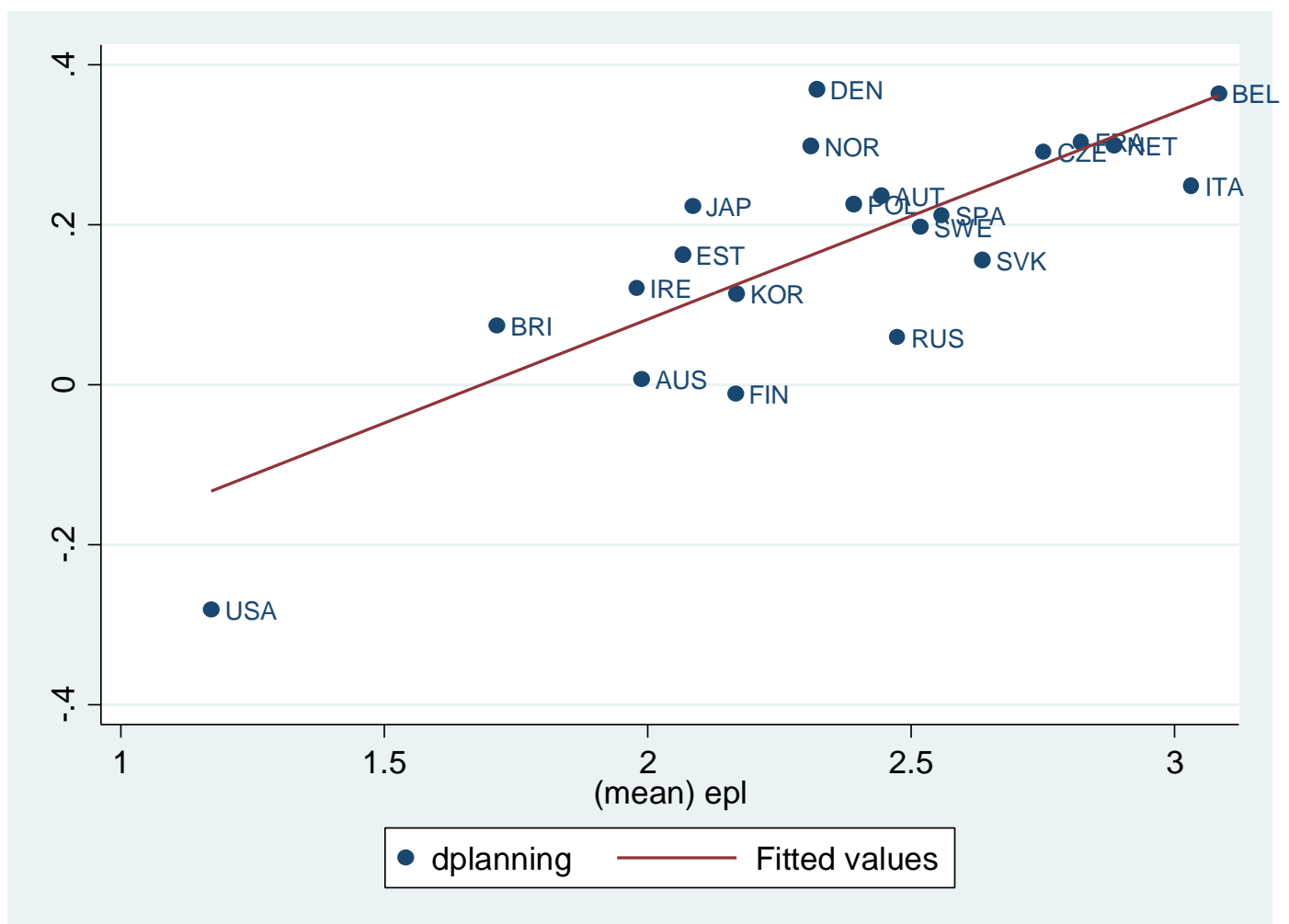

Slope of regression line is 0.2595 (robust standard error 0.0520) with USA and Australia included and 0.1694 (robust standard error 0.0354) with USA and Australia excluded. 
Figure 6: Average Use of Numeracy Skills in Permanent - Average Use of Numeracy Skills (dnumwork) in Temporary Jobs by Employment Protection Strictness (epl)

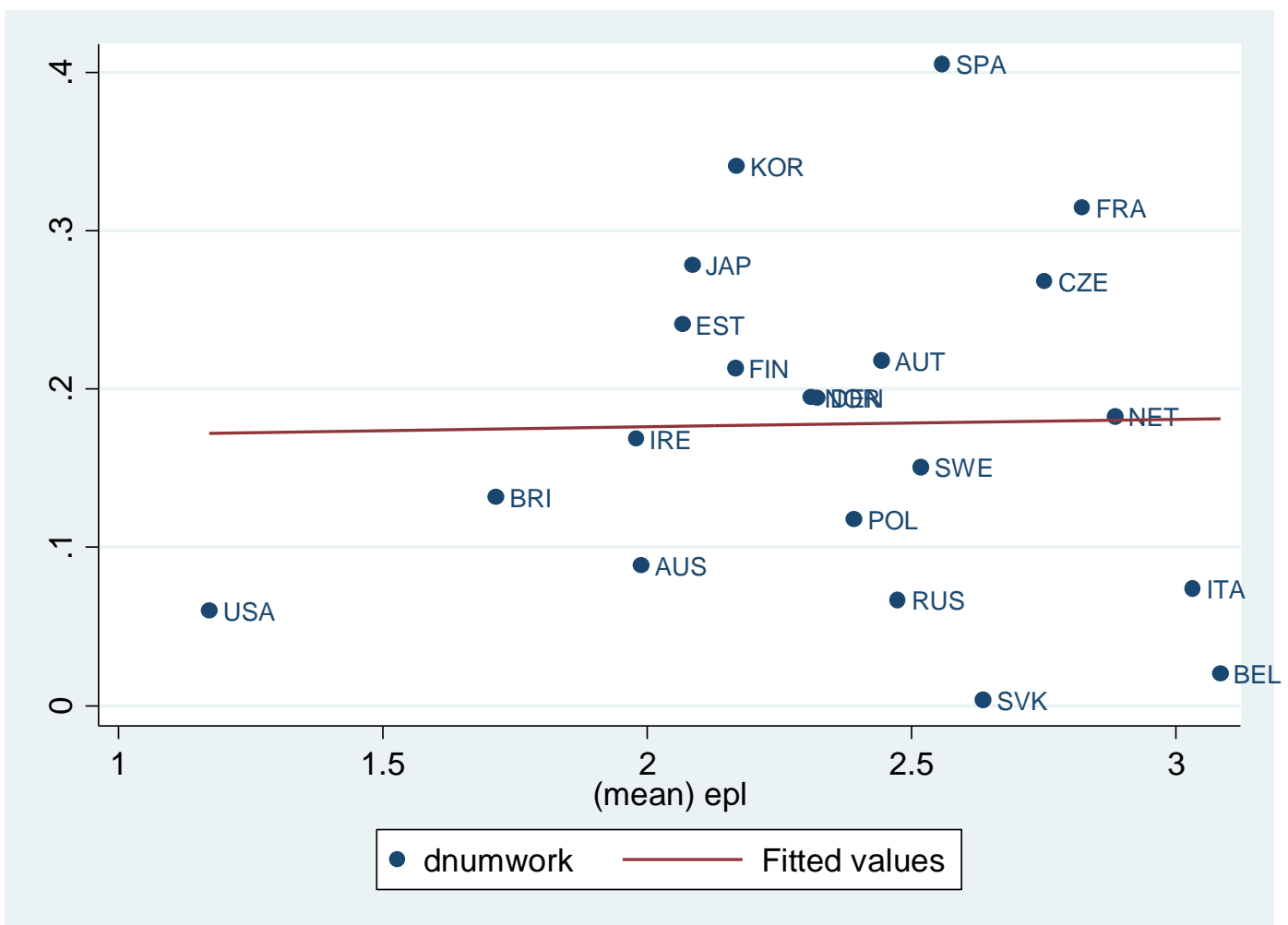

Slope of regression line is 0.0049 (robust standard error 0.0569) with USA and Australia included and -0.0694 (robust standard error 0.0656) with USA and Australia excluded. 
Figure 7: Average Use of Information and Computer Technology Skills in Permanent Average Use of Information and Computer Technology Skills (dictwork) in Temporary Jobs by Employment Protection Strictness (epl)

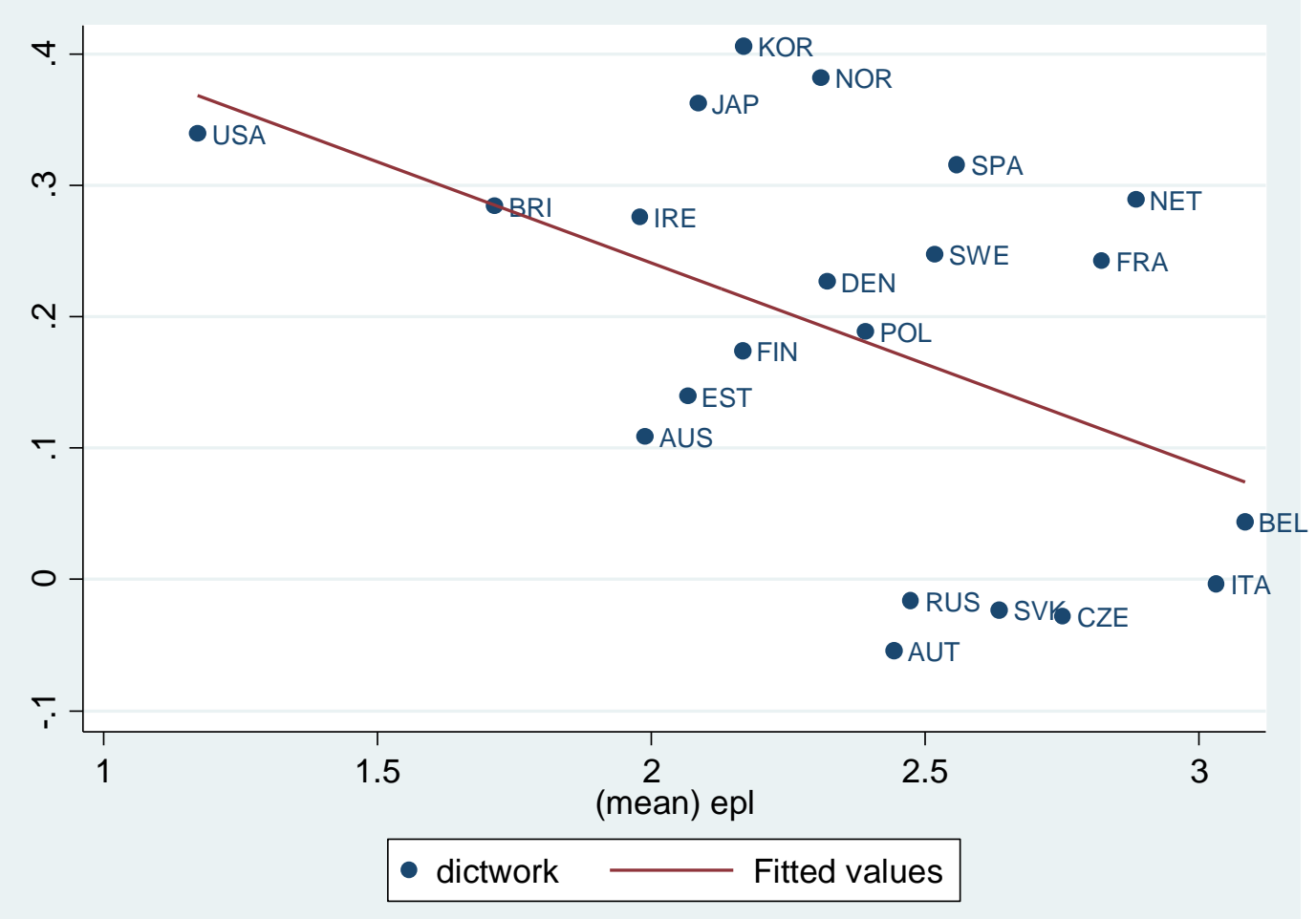

Slope of regression line is -0.1538 (robust standard error 0.0453) with USA and Australia included and -0.1940 (robust standard error 0.0647) with USA and Australia excluded. 
Table 1: PIAAC Job Content Variable Descriptions

\begin{tabular}{|c|c|}
\hline Reading & Reading documents (directions, instructions, letters, memos, e-mails, articles, books, manuals, bills, invoices, diagrams, maps) \\
\hline Writing & Writing documents (letters, memos, e-mails, articles, reports, forms) \\
\hline Numeracy & $\begin{array}{l}\text { Calculating prices, costs or budgets; use of fractions, decimals or percentages; use of calculators; preparing graphs or tables; } \\
\text { algebra or formulas; use of advanced math or statistics (calculus, trigonometry, regressions) }\end{array}$ \\
\hline ICT Skills & $\begin{array}{l}\text { Using e-mail, Internet, spreadsheets, word processors, programming languages; conducting transactions online; participating in } \\
\text { online discussions (conferences, chats) }\end{array}$ \\
\hline Task Discretion & Choosing or changing sequence of job tasks, the speed of work, working hours; choosing how to do the job \\
\hline Influencing Skills & $\begin{array}{l}\text { Instructing, teaching or training people; making speeches or presentations; selling products or services; advising people; planning } \\
\text { others' activities; persuading or influencing others; negotiating }\end{array}$ \\
\hline Planning & Organizing one's time \\
\hline
\end{tabular}

Source: OECD (2013c, p. 43) 
Table 2: Sample Means, Selected Variables

\begin{tabular}{|c|c|c|c|c|c|c|}
\hline & \multicolumn{2}{|c|}{ Men and Women Pooled } & \multicolumn{2}{|c|}{ Men } & \multicolumn{2}{|c|}{ Women } \\
\hline & \multicolumn{2}{|c|}{ Employment Contract Type } & \multicolumn{2}{|c|}{ Employment Contract Type } & \multicolumn{2}{|c|}{ Employment Contract Type } \\
\hline & Temporary & Permanent & Temporary & Permanent & Temporary & Permanent \\
\hline \multicolumn{7}{|l|}{ Job Content: } \\
\hline Reading & 1.933 & 2.059 & 1.934 & 2.085 & 1.933 & 2.031 \\
\hline Writing & 2.025 & 2.123 & 2.046 & 2.152 & 2.006 & 2.092 \\
\hline Influence & 1.993 & 2.062 & 1.968 & 2.066 & 2.015 & 2.057 \\
\hline Task Discretion & 1.710 & 1.899 & 1.710 & 1.937 & 1.709 & 1.857 \\
\hline Planning & 1.923 & 2.069 & 1.891 & 2.086 & 1.952 & 2.051 \\
\hline Numeracy Skills & 1.900 & 2.048 & 2.012 & 2.149 & 1.797 & 1.934 \\
\hline ICT Skills & 1.910 & 2.087 & 1.977 & 2.171 & 1.855 & 2.003 \\
\hline Years of Schooling & 13.461 & 13.398 & 13.115 & 13.241 & 13.777 & 13.572 \\
\hline Immigrant & 0.116 & 0.099 & 0.115 & 0.102 & 0.116 & 0.096 \\
\hline \multicolumn{7}{|l|}{ Actual Labor Market } \\
\hline Experience (yrs) & 14.371 & 19.550 & 15.593 & 20.217 & 13.252 & 18.817 \\
\hline Numeracy Test Score & 272.410 & 277.932 & 273.957 & 282.670 & 270.994 & 272.730 \\
\hline Literacy Test & 278.672 & 280.543 & 275.525 & 281.091 & 281.553 & 279.940 \\
\hline \multicolumn{7}{|l|}{ Problem Solving Test } \\
\hline Score & 287.887 & 286.580 & 287.875 & 289.728 & 287.898 & 283.180 \\
\hline Manager & 0.043 & 0.076 & 0.053 & 0.094 & 0.034 & 0.056 \\
\hline Prof/Tech & 0.356 & 0.378 & 0.317 & 0.343 & 0.391 & 0.418 \\
\hline Clerical/Sales/Service & 0.310 & 0.276 & 0.206 & 0.175 & 0.405 & 0.387 \\
\hline Blue Collar & 0.291 & 0.269 & 0.424 & 0.388 & 0.170 & 0.139 \\
\hline Female & 0.522 & 0.477 & & & & \\
\hline Total Sample Size & 9817 & 51414 & 4435 & 25364 & 5382 & 26050 \\
\hline
\end{tabular}

Source: PIAAC pooled 21 country sample. Sample weights are adjusted so that each country receives equal weight. Job Content variables are scaled to have mean 2.0 and variance 1.0. Some sample sizes are smaller for some of the job content variables and test scores due to missing data. Sample sizes reflect rounding of US sample size to the nearest 10. 
Table 3: Selected Regression Results for Job Content Variables, Pooled 21 Country Sample

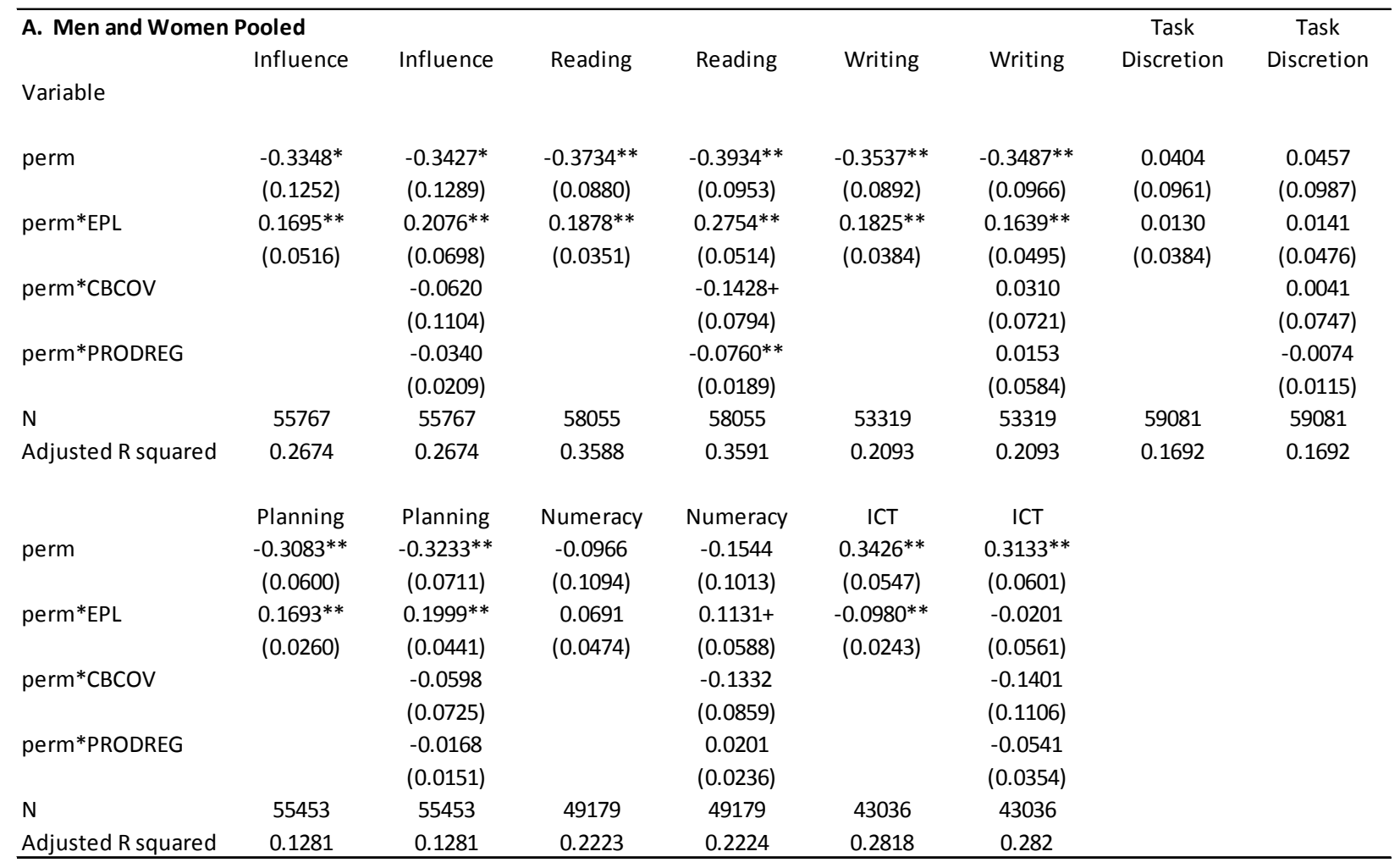


Table 3: Selected Regression Results for Job Content Variables, Pooled 21 Country Sample (ctd)

\begin{tabular}{|c|c|c|c|c|c|c|c|c|}
\hline $\begin{array}{l}\text { B. Men } \\
\text { Variable }\end{array}$ & Influence & Influence & Reading & Reading & Writing & Writing & $\begin{array}{c}\text { Task } \\
\text { Discretion }\end{array}$ & $\begin{array}{c}\text { Task } \\
\text { Discretion }\end{array}$ \\
\hline perm & $\begin{array}{c}-0.6096^{* *} \\
(0.1572)\end{array}$ & $\begin{array}{c}-0.6288^{* *} \\
(0.1624)\end{array}$ & $\begin{array}{c}-0.4364^{* *} \\
(0.0899)\end{array}$ & $\begin{array}{c}-0.4557^{* *} \\
(0.1019)\end{array}$ & $\begin{array}{c}-0.5579 * * \\
(0.1014)\end{array}$ & $\begin{array}{c}-0.5595^{* *} \\
(0.1075)\end{array}$ & $\begin{array}{c}0.1600 \\
(0.0992)\end{array}$ & $\begin{array}{c}0.1113 \\
(0.1042)\end{array}$ \\
\hline perm*EPL & $\begin{array}{c}0.2869 * * \\
(0.0659)\end{array}$ & $\begin{array}{c}0.3563^{* *} \\
(0.0817)\end{array}$ & $\begin{array}{c}0.2115^{* *} \\
(0.0366)\end{array}$ & $\begin{array}{c}0.3280^{* *} \\
(0.0582)\end{array}$ & $\begin{array}{l}0.2692^{* *} \\
(0.0451)\end{array}$ & $\begin{array}{c}0.2391^{* *} \\
(0.0643)\end{array}$ & $\begin{array}{l}-0.0339 \\
(0.0434)\end{array}$ & $\begin{array}{c}0.0246 \\
(0.0558)\end{array}$ \\
\hline perm*CBCOV & & $\begin{array}{l}-0.1165 \\
(0.1092)\end{array}$ & & $\begin{array}{c}-0.1767+ \\
(0.0976)\end{array}$ & & $\begin{array}{c}0.0374 \\
(0.1069)\end{array}$ & & $\begin{array}{l}-0.1343 \\
(0.0833)\end{array}$ \\
\hline perm*PRODREG & & $\begin{array}{l}-0.0570^{*} \\
(0.0259)\end{array}$ & & $\begin{array}{c}-0.1115^{* *} \\
(0.0210)\end{array}$ & & $\begin{array}{c}0.0370 \\
(0.0661)\end{array}$ & & $\begin{array}{l}-0.0103 \\
(0.0144)\end{array}$ \\
\hline $\mathrm{N}$ & 27118 & 27118 & 28327 & 28327 & 25779 & 25779 & 28726 & 28726 \\
\hline Adjusted R squared & 0.2841 & 0.2842 & 0.3691 & 0.3696 & 0.2164 & 0.2163 & 0.2034 & 0.2034 \\
\hline & Planning & Planning & Numeracy & Numeracy & ICT & ICT & & \\
\hline perm & $\begin{array}{c}-0.2734^{* *} \\
(0.0570)\end{array}$ & $\begin{array}{c}-0.2975^{* *} \\
(0.0627)\end{array}$ & $\begin{array}{c}-0.1779+ \\
(0.0971)\end{array}$ & $\begin{array}{c}-0.2140^{*} \\
(0.0980)\end{array}$ & $\begin{array}{c}0.4779 * * \\
(0.1000)\end{array}$ & $\begin{array}{l}0.4316^{* *} \\
(0.1168)\end{array}$ & & \\
\hline perm*EPL & $\begin{array}{c}0.1661^{* *} \\
(0.0261)\end{array}$ & $\begin{array}{c}0.2406^{* *} \\
(0.0402)\end{array}$ & $\begin{array}{l}0.0912+ \\
(0.0441)\end{array}$ & $\begin{array}{l}0.1487^{*} \\
(0.0612)\end{array}$ & $\begin{array}{c}-0.1550 * * \\
(0.0444)\end{array}$ & $\begin{array}{c}0.0061 \\
(0.0817)\end{array}$ & & \\
\hline perm*CBCOV & & $\begin{array}{l}-0.1280 \\
(0.0845)\end{array}$ & & $\begin{array}{l}-0.1226 \\
(0.0914)\end{array}$ & & $\begin{array}{c}-0.2627+ \\
(0.1369)\end{array}$ & & \\
\hline perm*PRODREG & & $\begin{array}{c}-0.0569 * * \\
(0.0147)\end{array}$ & & $\begin{array}{l}-0.0227 \\
(0.0295)\end{array}$ & & $\begin{array}{c}-0.1357^{* *} \\
(0.0273)\end{array}$ & & \\
\hline $\mathrm{N}$ & 26946 & 26946 & 24266 & 24266 & 20034 & 20034 & & \\
\hline Adjusted R squared & 0.1249 & 0.1249 & 0.2401 & 0.2401 & 0.2961 & 0.2966 & & \\
\hline
\end{tabular}


Table 3: Selected Regression Results for Job Content Variables, Pooled 21 Country Sample (ctd)

\begin{tabular}{|c|c|c|c|c|c|c|c|c|}
\hline $\begin{array}{l}\text { C. Women } \\
\text { Variable }\end{array}$ & Influence & Influence & Reading & Reading & Writing & Writing & $\begin{array}{c}\text { Task } \\
\text { Discretion }\end{array}$ & $\begin{array}{c}\text { Task } \\
\text { Discretion }\end{array}$ \\
\hline perm & $\begin{array}{c}-0.0729 \\
(0.0854)\end{array}$ & $\begin{array}{l}-0.0420 \\
(0.0938)\end{array}$ & $\begin{array}{c}-0.3417^{* *} \\
(0.0788)\end{array}$ & $\begin{array}{c}-0.3517^{* *} \\
(0.0838)\end{array}$ & $\begin{array}{c}-0.1574+ \\
(0.0771)\end{array}$ & $\begin{array}{c}-0.1514+ \\
(0.0847)\end{array}$ & $\begin{array}{c}-0.1003 \\
(0.1098)\end{array}$ & $\begin{array}{l}-0.0429 \\
(0.1104)\end{array}$ \\
\hline perm*EPL & $\begin{array}{c}0.0577 \\
(0.0392)\end{array}$ & $\begin{array}{c}0.0349 \\
(0.0660)\end{array}$ & $\begin{array}{l}0.1736^{* *} \\
(0.0320)\end{array}$ & $\begin{array}{c}0.2219^{* *} \\
(0.0408)\end{array}$ & $\begin{array}{l}0.0964^{* *} \\
(0.0325)\end{array}$ & $\begin{array}{l}0.0982^{*} \\
(0.0410)\end{array}$ & $\begin{array}{c}0.0664 \\
(0.0446)\end{array}$ & $\begin{array}{c}0.0121 \\
(0.0563)\end{array}$ \\
\hline perm*CBCOV & & $\begin{array}{c}0.0670 \\
(0.1241)\end{array}$ & & $\begin{array}{l}-0.0796 \\
(0.0568)\end{array}$ & & $\begin{array}{c}0.0045 \\
(0.0654)\end{array}$ & & $\begin{array}{c}0.1398 \\
(0.0857)\end{array}$ \\
\hline perm*PRODREG & & $\begin{array}{l}-0.0114 \\
(0.0280)\end{array}$ & & $\begin{array}{c}-0.0421+ \\
(0.0205)\end{array}$ & & $\begin{array}{c}-0.0093 \\
(0.0549)\end{array}$ & & $\begin{array}{l}-0.0069 \\
(0.0204)\end{array}$ \\
\hline $\mathrm{N}$ & 28649 & 28649 & 29728 & 29728 & 27540 & 27540 & 30355 & 30355 \\
\hline Adjusted R squared & 0.2601 & 0.2601 & 0.3518 & 0.3518 & 0.2069 & 0.2068 & 0.3526 & 0.3527 \\
\hline & Planning & Planning & Numeracy & Numeracy & ICT & ICT & & \\
\hline perm & $\begin{array}{c}-0.3409^{* *} \\
(0.0907)\end{array}$ & $\begin{array}{c}-0.3400^{* *} \\
(0.0964)\end{array}$ & $\begin{array}{l}-0.0506 \\
(0.1410)\end{array}$ & $\begin{array}{l}-0.1334 \\
(0.1279)\end{array}$ & $\begin{array}{l}0.2029 * * \\
(0.0530)\end{array}$ & $\begin{array}{c}0.1855^{* *} \\
(0.0643)\end{array}$ & & \\
\hline perm*EPL & $\begin{array}{c}0.1731^{* *} \\
(0.0400)\end{array}$ & $\begin{array}{l}0.1597^{*} \\
(0.0589)\end{array}$ & $\begin{array}{c}0.0575 \\
(0.0599)\end{array}$ & $\begin{array}{c}0.0923 \\
(0.0663)\end{array}$ & $\begin{array}{l}-0.0415 \\
(0.0252)\end{array}$ & $\begin{array}{c}-0.0391 \\
(0.0543)\end{array}$ & & \\
\hline perm*CBCOV & & $\begin{array}{c}0.0205 \\
(0.0912)\end{array}$ & & $\begin{array}{l}-0.1540 \\
(0.0973)\end{array}$ & & $\begin{array}{c}-0.0229 \\
(0.1094)\end{array}$ & & \\
\hline perm*PRODREG & & $\begin{array}{c}0.0136 \\
(0.0278)\end{array}$ & & $\begin{array}{c}0.0627^{* *} \\
(0.0203)\end{array}$ & & $\begin{array}{c}0.0187 \\
(0.0616)\end{array}$ & & \\
\hline $\mathrm{N}$ & 28517 & 28517 & 24903 & 24903 & 22992 & 22992 & & \\
\hline Adjusted R squared & 0.14 & 0.1399 & 0.1933 & 0.1937 & 0.2677 & 0.2677 & & \\
\hline
\end{tabular}

$+,{ }^{*}, * *$ significant at $10 \%, 5 \%$ and $1 \%$ levels, respectively.

Controls include years of schooling, experience and its square, immigrant dummy, numeracy test score, literacy test score, government employment dummy, industry, occupation and country dummies, and in the sample pooled by gender, a female dummy variable.

Adjusted sampling weights used, where each country receives the same weight. Standard errors clustered at the country level. Sample sizes reflect rounding of the US sample size to the nearest 10. 
Table 4: Selected Regression Results for Job Content Variables, Pooled 20 Country Sample, Industry, Occupation, and Government Employment Dummies Excluded

\begin{tabular}{|c|c|c|c|c|c|c|c|c|}
\hline \multicolumn{7}{|c|}{ A. Men and Women Pooled } & \multirow{3}{*}{$\begin{array}{l}\text { Task } \\
\text { Discretion }\end{array}$} & \multirow{3}{*}{$\begin{array}{l}\text { Task } \\
\text { Discretion }\end{array}$} \\
\hline & Influence & Influence & Reading & Reading & Writing & Writing & & \\
\hline \multicolumn{7}{|l|}{ Variable } & & \\
\hline \multirow[t]{2}{*}{ perm } & $-0.5101^{* *}$ & $-0.5395^{* *}$ & $-0.4642^{* *}$ & $-0.5012^{* *}$ & $-0.3275^{* *}$ & $-0.3240 * *$ & 0.1329 & 0.1634 \\
\hline & $(0.1698)$ & $(0.1721)$ & $(0.1026)$ & $(0.1078)$ & $(0.0676)$ & $(0.0775)$ & $(0.1145)$ & $(0.1125)$ \\
\hline \multirow[t]{2}{*}{ perm*EPL } & $0.2319 * *$ & $0.2912^{* *}$ & $0.2296 * *$ & $0.3419 * *$ & $0.1863^{* *}$ & $0.1834^{* *}$ & -0.0161 & -0.0256 \\
\hline & $(0.0684)$ & $(0.0836)$ & $(0.0421)$ & $(0.0563)$ & $(0.0285)$ & $(0.0398)$ & $(0.0459)$ & $(0.0515)$ \\
\hline \multirow[t]{2}{*}{ perm*CBCOV } & & -0.1163 & & $-0.1966^{*}$ & & 0.0083 & & 0.0469 \\
\hline & & $(0.1080)$ & & $(0.0764)$ & & $(0.0669)$ & & $(0.0735)$ \\
\hline \multirow[t]{2}{*}{ perm*PRODREG } & & $-0.0322+$ & & $-0.0837 * *$ & & -0.0010 & & $-0.0249 *$ \\
\hline & & $(0.0176)$ & & $(0.0210)$ & & $(0.0538)$ & & $(0.0107)$ \\
\hline $\mathrm{N}$ & 55767 & 55767 & 58055 & 58055 & 53319 & 53319 & 59081 & 59081 \\
\hline \multirow[t]{2}{*}{ Adjusted R squared } & 0.1552 & 0.1553 & 0.253 & 0.2534 & 0.1314 & 0.1313 & 0.1142 & 0.1143 \\
\hline & Planning & Planning & Numeracy & Numeracy & ICT & ICT & & \\
\hline \multirow[t]{2}{*}{ perm } & $-0.3715^{* *}$ & $-0.3976 * *$ & $0.1265+$ & 0.1391 & $0.5599 * *$ & $0.5879 * *$ & & \\
\hline & $(0.0982)$ & $(0.1056)$ & $(0.0715)$ & $(0.0819)$ & $(0.0643)$ & $(0.0669)$ & & \\
\hline \multirow[t]{2}{*}{ perm*EPL } & $0.1943 * *$ & $0.2384 * *$ & 0.0108 & 0.0287 & $-0.1625^{* *}$ & $-0.1072+$ & & \\
\hline & $(0.0392)$ & $(0.0527)$ & $(0.0336)$ & $(0.0567)$ & $(0.0321)$ & $(0.0603)$ & & \\
\hline \multirow[t]{2}{*}{ perm*CBCOV } & & -0.0917 & & -0.0059 & & -0.0416 & & \\
\hline & & $(0.0756)$ & & (0.0990) & & $(0.1128)$ & & \\
\hline \multirow[t]{2}{*}{ perm*PRODREG } & & -0.0187 & & -0.0365 & & $-0.0988 * *$ & & \\
\hline & & $(0.0145)$ & & $(0.0292)$ & & $(0.0259)$ & & \\
\hline $\mathrm{N}$ & 55453 & 55453 & 49179 & 49179 & 43036 & 43036 & & \\
\hline Adjusted R squared & 0.0808 & 0.0809 & 0.109 & 0.109 & 0.1333 & 0.1336 & & \\
\hline
\end{tabular}


Table 4: Selected Regression Results for Job Content Variables, Pooled 20 Country Sample, Industry, Occupation, and Government Employment Dummies Excluded (ctd)

\begin{tabular}{|c|c|c|c|c|c|c|c|c|}
\hline \multirow[t]{2}{*}{ B. Men } & & & & & & & Task & Task \\
\hline & Influence & Influence & Reading & Reading & Writing & Writing & Discretion & Discretion \\
\hline \multicolumn{9}{|l|}{ Variable } \\
\hline \multirow[t]{2}{*}{ perm } & $-0.7130 * *$ & $-0.7463 * *$ & $-0.5347 * *$ & $-0.5675^{* *}$ & $-0.5914 * *$ & $-0.5814^{* *}$ & $0.2304+$ & 0.2140 \\
\hline & $(0.1697)$ & $(0.1763)$ & $(0.0866)$ & $(0.0994)$ & $(0.0638)$ & $(0.0773)$ & $(0.1238)$ & $(0.1284)$ \\
\hline \multirow[t]{2}{*}{ perm*EPL } & $0.3215^{* *}$ & $0.4402 * *$ & $0.2540 * *$ & $0.4257^{* *}$ & $0.2932 * *$ & $0.2963^{* *}$ & -0.0539 & -0.0100 \\
\hline & $(0.0702)$ & $(0.0854)$ & $(0.0382)$ & $(0.0547)$ & $(0.0275)$ & $(0.0486)$ & $(0.0527)$ & $(0.0676)$ \\
\hline \multirow[t]{2}{*}{ perm*CBCOV } & & $-0.2017^{*}$ & & $-0.2676^{* *}$ & & 0.0087 & & -0.0788 \\
\hline & & $(0.0948)$ & & $(0.0833)$ & & (0.0939) & & $(0.0971)$ \\
\hline \multirow[t]{2}{*}{ perm*PRODREG } & & $-0.0964 *$ & & $-0.1582^{* *}$ & & -0.0158 & & -0.0306 \\
\hline & & $(0.0348)$ & & $(0.0301)$ & & $(0.0521)$ & & $(0.0180)$ \\
\hline N & 27118 & 27118 & 28327 & 28327 & 25779 & 25779 & 28726 & 28726 \\
\hline \multirow[t]{2}{*}{ Adjusted R squared } & 0.1587 & 0.159 & 0.2638 & 0.2648 & 0.1402 & 0.1402 & 0.1389 & 0.1389 \\
\hline & Planning & Planning & Numeracy & Numeracy & ICT & ICT & & \\
\hline \multirow[t]{2}{*}{ perm } & $-0.2773^{* *}$ & $-0.3023^{* *}$ & 0.0050 & 0.0475 & $0.6441^{* *}$ & $0.6829 * *$ & & \\
\hline & $(0.0694)$ & $(0.0722)$ & $(0.0672)$ & $(0.0804)$ & $(0.1389)$ & $(0.1398)$ & & \\
\hline \multirow[t]{2}{*}{ perm*EPL } & $0.1701^{* *}$ & $0.2682 * *$ & 0.0493 & 0.0686 & $-0.2022 * *$ & -0.0662 & & \\
\hline & $(0.0316)$ & $(0.0470)$ & (0.0349) & $(0.0540)$ & $(0.0664)$ & $(0.0835)$ & & \\
\hline \multirow[t]{2}{*}{ perm*CBCOV } & & -0.1619 & & 0.0331 & & -0.1246 & & \\
\hline & & $(0.0996)$ & & $(0.0770)$ & & $(0.1086)$ & & \\
\hline \multirow[t]{2}{*}{ perm*PRODREG } & & $-0.0820 * *$ & & $-0.0753^{*}$ & & $-0.2116 * *$ & & \\
\hline & & $(0.0235)$ & & $(0.0286)$ & & $(0.0394)$ & & \\
\hline N & 26946 & 26946 & 24266 & 24266 & 20034 & 20034 & & \\
\hline Adjusted R squared & 0.0728 & 0.0731 & 0.1342 & 0.1344 & 0.1487 & 0.1496 & & \\
\hline
\end{tabular}


Table 4: Selected Regression Results for Job Content Variables, Pooled 20 Country Sample, Industry, Occupation, and Government Employment Dummies Excluded (ctd)

\begin{tabular}{|c|c|c|c|c|c|c|c|c|}
\hline \multirow[t]{2}{*}{ C. Women } & & & & & & & Task & Task \\
\hline & Influence & Influence & Reading & Reading & Writing & Writing & Discretion & Discretion \\
\hline \multicolumn{9}{|l|}{ Variable } \\
\hline \multirow[t]{2}{*}{ perm } & $-0.3325^{*}$ & $-0.3371+$ & $-0.4160^{* *}$ & $-0.4493 * *$ & -0.0766 & -0.0846 & 0.0048 & 0.0798 \\
\hline & $(0.1534)$ & $(0.1663)$ & $(0.1146)$ & $(0.1198)$ & $(0.0806)$ & $(0.0926)$ & (0.1198) & $(0.1148)$ \\
\hline \multirow[t]{2}{*}{ perm*EPL } & $0.1519^{*}$ & 0.1309 & $0.2113^{* *}$ & $0.2564^{* *}$ & $0.0836^{*}$ & $0.0851+$ & 0.0332 & -0.0279 \\
\hline & $(0.0652)$ & $(0.0963)$ & $(0.0473)$ & $(0.0590)$ & $(0.0340)$ & $(0.0455)$ & $(0.0488)$ & $(0.0564)$ \\
\hline \multirow[t]{2}{*}{ perm*CBCOV } & & 0.0245 & & -0.1018 & & -0.0117 & & $0.1696+$ \\
\hline & & $(0.1481)$ & & $(0.0719)$ & & $(0.0742)$ & & $(0.0897)$ \\
\hline \multirow[t]{2}{*}{ perm*PRODREG } & & 0.0292 & & -0.0106 & & 0.0082 & & -0.0206 \\
\hline & & $(0.0397)$ & & $(0.0226)$ & & $(0.0547)$ & & (0.0193) \\
\hline $\mathrm{N}$ & 28649 & 28649 & 29728 & 29728 & 27540 & 27540 & 30355 & 30355 \\
\hline \multirow[t]{2}{*}{ Adjusted R squared } & 0.1587 & 0.1586 & 0.2437 & 0.2437 & 0.1232 & 0.1232 & 0.0882 & 0.0884 \\
\hline & Planning & Planning & Numeracy & Numeracy & ICT & ICT & & \\
\hline \multirow[t]{2}{*}{ perm } & $-0.4534^{* *}$ & $-0.4750^{* *}$ & 0.2038 & 0.1765 & $0.4446 * *$ & $0.4595^{* *}$ & & \\
\hline & $(0.1561)$ & $(0.1582)$ & $(0.1220)$ & $(0.1233)$ & $(0.0704)$ & $(0.0795)$ & & \\
\hline \multirow[t]{2}{*}{ perm*EPL } & $0.2166^{* *}$ & $0.2051^{*}$ & -0.0163 & 0.0132 & $-0.1144 * *$ & $-0.1174+$ & & \\
\hline & $(0.0645)$ & $(0.0775)$ & $(0.0505)$ & $(0.0747)$ & $(0.0297)$ & $(0.0583)$ & & \\
\hline \multirow[t]{2}{*}{ perm*CBCOV } & & -0.0079 & & -0.0751 & & 0.0215 & & \\
\hline & & $(0.0988)$ & & $(0.1410)$ & & $(0.1261)$ & & \\
\hline \multirow[t]{2}{*}{ perm*PRODREG } & & 0.0385 & & 0.0003 & & -0.0152 & & \\
\hline & & $(0.0327)$ & & $(0.0291)$ & & $(0.0515)$ & & \\
\hline$N$ & 28517 & 28517 & 24903 & 24903 & 22992 & 22992 & & \\
\hline Adjusted R squared & 0.0947 & 0.0947 & 0.0769 & 0.0769 & 0.1111 & 0.1111 & & \\
\hline
\end{tabular}

$+,{ }^{*}, * *$ significant at $10 \%, 5 \%$ and $1 \%$ levels, respectively.

Controls include years of schooling, experience and its square, immigrant dummy, numeracy test score, literacy test score, country dummies, and female dummy variable for the sample pooled by gender.

Adjusted sampling weights used, where each country receives the same weight. Standard errors clustered at the country level.

Sample sizes reflect rounding of the US sample size to the nearest 10. 
Table 5: Selected Regression Results for Job Content Variables, Pooled 21 Country Sample, Industry, Occupation, and Government Employment Dummies and Human Capital Variables Excluded

\begin{tabular}{|c|c|c|c|c|c|c|c|c|}
\hline \multicolumn{7}{|c|}{ A. Men and Women Pooled } & \multirow{3}{*}{$\begin{array}{c}\text { Task } \\
\text { Discretion }\end{array}$} & \multirow{3}{*}{$\begin{array}{c}\text { Task } \\
\text { Discretion }\end{array}$} \\
\hline & Influence & Influence & Reading & Reading & Writing & Writing & & \\
\hline \multicolumn{7}{|l|}{ Variable } & & \\
\hline \multirow[t]{2}{*}{ perm } & $-0.7085^{* *}$ & $-0.7481^{* *}$ & $-0.7126 * *$ & $-0.7627^{* *}$ & $-0.4529 * *$ & $-0.4606^{* *}$ & 0.0070 & 0.0513 \\
\hline & $(0.2296)$ & $(0.2351)$ & $(0.1710)$ & $(0.1811)$ & $(0.1054)$ & $(0.1139)$ & $(0.0947)$ & $(0.0898)$ \\
\hline \multirow[t]{2}{*}{ perm*EPL } & $0.3448 * *$ & $0.4458^{* *}$ & $0.3684 * *$ & $0.5197^{* *}$ & $0.2620 * *$ & $0.2847 * *$ & 0.0600 & 0.0632 \\
\hline & $(0.0930)$ & $(0.1134)$ & $(0.0720)$ & $(0.0951)$ & $(0.0425)$ & $(0.0596)$ & $(0.0378)$ & $(0.0436)$ \\
\hline \multirow[t]{2}{*}{ perm*CBCOV } & & -0.1864 & & $-0.2660^{*}$ & & -0.0399 & & 0.0426 \\
\hline & & $(0.1306)$ & & $(0.1202)$ & & $(0.0701)$ & & $(0.0734)$ \\
\hline \multirow[t]{2}{*}{ perm*PRODREG } & & $-0.0674 *$ & & $-0.1125+$ & & -0.0167 & & $-0.0551^{* *}$ \\
\hline & & $(0.0269)$ & & $(0.0559)$ & & $(0.0376)$ & & $(0.0166)$ \\
\hline N & 55767 & 55767 & 58055 & 58055 & 53319 & 53319 & 59081 & 59081 \\
\hline \multirow[t]{2}{*}{ Adjusted R squared } & 0.0487 & 0.049 & 0.0521 & 0.0529 & 0.0473 & 0.0473 & 0.0725 & 0.0727 \\
\hline & Planning & Planning & Numeracy & Numeracy & ICT & ICT & & \\
\hline \multirow[t]{2}{*}{ perm } & $-0.5030 * *$ & $-0.5126^{* *}$ & 0.0868 & 0.0777 & $0.5157^{* *}$ & $0.5163^{* *}$ & & \\
\hline & $(0.1295)$ & $(0.1388)$ & (0.0998) & $(0.1028)$ & $(0.0844)$ & $(0.0877)$ & & \\
\hline \multirow[t]{2}{*}{ perm*EPL } & $0.2824 * *$ & $0.3441 * *$ & 0.0357 & 0.0976 & $-0.1379 * *$ & -0.0406 & & \\
\hline & $(0.0528)$ & $(0.0656)$ & $(0.0443)$ & $(0.0617)$ & $(0.0415)$ & $(0.0715)$ & & \\
\hline \multirow[t]{2}{*}{ perm*CBCOV } & & -0.0980 & & -0.0927 & & -0.1324 & & \\
\hline & & $(0.0743)$ & & $(0.0927)$ & & $(0.1249)$ & & \\
\hline \multirow[t]{2}{*}{ perm*PRODREG } & & $-0.0576^{*}$ & & $-0.0607^{* *}$ & & $-0.1134^{* *}$ & & \\
\hline & & $(0.0257)$ & & $(0.0212)$ & & $(0.0237)$ & & \\
\hline$N$ & 55453 & 55453 & 49179 & 49179 & 43036 & 43036 & & \\
\hline Adjusted R squared & 0.0336 & 0.0337 & 0.0301 & 0.0302 & 0.0383 & 0.0386 & & \\
\hline
\end{tabular}


Table 5: Selected Regression Results for Job Content Variables, Pooled 21 Country Sample, Industry, Occupation, and Government Employment Dummies and Human Capital Variables Excluded (ctd)

\begin{tabular}{|c|c|c|c|c|c|c|c|c|}
\hline \multirow[t]{2}{*}{ B. Men } & & & & & & & Task & Task \\
\hline & Influence & Influence & Reading & Reading & Writing & Writing & Discretion & Discretion \\
\hline \multicolumn{9}{|l|}{ Variable } \\
\hline \multirow[t]{2}{*}{ perm } & $-0.8718^{* *}$ & $-0.8906 * *$ & $-0.7307^{* *}$ & $-0.7579 * *$ & $-0.6525^{* *}$ & $-0.6426 * *$ & 0.0968 & 0.1108 \\
\hline & $(0.2032)$ & (0.2129) & (0.1098) & $(0.1231)$ & $(0.0801)$ & $(0.0897)$ & $(0.1127)$ & $(0.1132)$ \\
\hline \multirow[t]{2}{*}{ perm*EPL } & $0.4303^{* *}$ & $0.5658 * *$ & $0.3835^{* *}$ & $0.5702 * *$ & $0.3505^{* *}$ & $0.3590 * *$ & 0.0339 & 0.0795 \\
\hline & $(0.0836)$ & $(0.0982)$ & $(0.0516)$ & $(0.0716)$ & $(0.0346)$ & $(0.0577)$ & $(0.0470)$ & $(0.0607)$ \\
\hline \multirow[t]{2}{*}{ perm*CBCOV } & & $-0.2082+$ & & $-0.2818^{*}$ & & 0.0011 & & -0.0475 \\
\hline & & (0.1088) & & (0.1115) & & $(0.0886)$ & & (0.1026) \\
\hline \multirow[t]{2}{*}{ perm*PRODREG } & & $-0.1327^{*}$ & & $-0.1823 * *$ & & -0.0219 & & $-0.0678^{*}$ \\
\hline & & $(0.0601)$ & & $(0.0604)$ & & $(0.0354)$ & & $(0.0315)$ \\
\hline N & 27118 & 27118 & 28327 & 28327 & 25779 & 25779 & 28726 & 28726 \\
\hline \multirow[t]{2}{*}{ Adjusted R squared } & 0.0473 & 0.0479 & 0.0688 & 0.0701 & 0.0558 & 0.0558 & 0.0813 & 0.0814 \\
\hline & Planning & Planning & Numeracy & Numeracy & ICT & ICT & & \\
\hline \multirow[t]{2}{*}{ perm } & $-0.3742^{* *}$ & $-0.3603^{* *}$ & -0.0141 & 0.0167 & $0.6596 * *$ & $0.6771^{* *}$ & & \\
\hline & $(0.0769)$ & $(0.0851)$ & $(0.0772)$ & $(0.0898)$ & $(0.1304)$ & $(0.1269)$ & & \\
\hline \multirow[t]{2}{*}{ perm*EPL } & $0.2498 * *$ & $0.3446 * *$ & $0.0769+$ & $0.1260+$ & $-0.1896^{*}$ & -0.0342 & & \\
\hline & $(0.0347)$ & $(0.0505)$ & $(0.0413)$ & $(0.0630)$ & $(0.0668)$ & $(0.0810)$ & & \\
\hline \multirow[t]{2}{*}{ perm*CBCOV } & & -0.1125 & & -0.0225 & & -0.1771 & & \\
\hline & & $(0.1061)$ & & $(0.0880)$ & & $(0.1130)$ & & \\
\hline \multirow[t]{2}{*}{ perm*PRODREG } & & $-0.1238 *$ & & $-0.0955^{* *}$ & & $-0.2084^{* *}$ & & \\
\hline & & $(0.0470)$ & & $(0.0270)$ & & $(0.0597)$ & & \\
\hline$N$ & 26946 & 26946 & 24266 & 24266 & 20034 & 20034 & & \\
\hline Adjusted R squared & 0.0325 & 0.0329 & 0.0251 & 0.0253 & 0.0316 & 0.0326 & & \\
\hline
\end{tabular}


Table 5: Selected Regression Results for Job Content Variables, Pooled 21 Country Sample, Industry, Occupation, and Government Employment Dummies and Human Capital Variables Excluded (ctd)

\begin{tabular}{|c|c|c|c|c|c|c|c|c|}
\hline \multirow[t]{2}{*}{ C. Women } & & & & & & & Task & Task \\
\hline & Influence & Influence & Reading & Reading & Writing & Writing & Discretion & Discretion \\
\hline \multicolumn{9}{|l|}{ Variable } \\
\hline \multirow[t]{2}{*}{ perm } & $-0.5843^{*}$ & $-0.6090^{*}$ & $-0.7325^{* *}$ & $-0.7795^{* *}$ & $-0.2778^{*}$ & $-0.2957^{*}$ & -0.1119 & -0.0288 \\
\hline & $(0.2348)$ & $(0.2477)$ & $(0.2138)$ & $(0.2268)$ & $(0.1249)$ & $(0.1371)$ & $(0.1008)$ & $(0.0940)$ \\
\hline \multirow[t]{2}{*}{ perm*EPL } & $0.2723^{*}$ & $0.3003^{*}$ & $0.3647^{* *}$ & $0.4534^{* *}$ & $0.1822^{* *}$ & $0.2149 * *$ & $0.0972^{*}$ & 0.0496 \\
\hline & $(0.0976)$ & $(0.1319)$ & $(0.0888)$ & $(0.1108)$ & $(0.0492)$ & $(0.0682)$ & $(0.0416)$ & $(0.0510)$ \\
\hline \multirow[t]{2}{*}{ perm*CBCOV } & & -0.0678 & & -0.1791 & & -0.0662 & & $0.1570+$ \\
\hline & & $(0.1718)$ & & $(0.1225)$ & & $(0.0786)$ & & (0.0859) \\
\hline \multirow[t]{2}{*}{ perm*PRODREG } & & -0.0015 & & -0.0431 & & -0.0154 & & $-0.0450^{* *}$ \\
\hline & & $(0.0300)$ & & $(0.0593)$ & & $(0.0397)$ & & $(0.0115)$ \\
\hline $\mathrm{N}$ & 28649 & 28649 & 29728 & 29728 & 27540 & 27540 & 30355 & 30355 \\
\hline \multirow[t]{2}{*}{ Adjusted R squared } & 0.0599 & 0.0599 & 0.0414 & 0.0416 & 0.0398 & 0.0398 & 0.0625 & 0.0629 \\
\hline & Planning & Planning & Numeracy & Numeracy & ICT & ICT & & \\
\hline \multirow[t]{2}{*}{ perm } & $-0.6365^{* *}$ & $-0.6555^{* *}$ & 0.1739 & 0.1304 & $0.3549 * *$ & $0.3494 * *$ & & \\
\hline & (0.1995) & $(0.2029)$ & $(0.1432)$ & $(0.1403)$ & $(0.1058)$ & $(0.1127)$ & & \\
\hline \multirow[t]{2}{*}{ perm*EPL } & $0.3172^{* *}$ & $0.3356^{* *}$ & -0.0048 & 0.0621 & $-0.0801+$ & -0.0405 & & \\
\hline & $(0.0823)$ & $(0.0943)$ & $(0.0594)$ & $(0.0774)$ & (0.0439) & $(0.0735)$ & & \\
\hline \multirow[t]{2}{*}{ perm*CBCOV } & & -0.0481 & & -0.1453 & & -0.0637 & & \\
\hline & & $(0.0922)$ & & (0.1304) & & (0.1379) & & \\
\hline \multirow[t]{2}{*}{ perm*PRODREG } & & 0.0024 & & -0.0226 & & -0.0373 & & \\
\hline & & $(0.0200)$ & & $(0.0249)$ & & $(0.0343)$ & & \\
\hline$N$ & 28517 & 28517 & 24903 & 24903 & 22992 & 22992 & & \\
\hline Adjusted R squared & 0.0376 & 0.0375 & 0.0301 & 0.0301 & 0.0387 & 0.0387 & & \\
\hline
\end{tabular}

$+,{ }^{*}, * *$ significant at $10 \%, 5 \%$ and $1 \%$ levels, respectively.

Controls include country dummies and for the sample pooled by gender, a female dummy variable.

Adjusted sampling weights used, where each country receives the same weight. Standard errors clustered at the country level.

Sample sizes reflect rounding of US sample sizes to the nearest 10. 
Table 6: Log Wage Impact Caused by Job Content Effects of Belgian-US Difference in EPL (based on models pooling countries and genders)

\begin{tabular}{|c|c|c|c|c|}
\hline \multirow{2}{*}{$\begin{array}{l}\text { A. United States and Australia in Sample } \\
\text { Job Content Models }\end{array}$} & \multicolumn{2}{|c|}{$\begin{array}{l}\text { perm*CBCOV, perm*PRODREG } \\
\text { Interactions Excluded from } \\
\text { Job Content Equations }\end{array}$} & \multicolumn{2}{|c|}{$\begin{array}{c}\text { perm*CBCOV, perm*PRODREG } \\
\text { Interactions Included in } \\
\text { Job Content Equations }\end{array}$} \\
\hline & $\begin{array}{l}\text { Human Capital } \\
\text { in Wage Eqn }\end{array}$ & $\begin{array}{l}\text { Human Capital } \\
\text { out of Wage Eqn }\end{array}$ & $\begin{array}{l}\text { Human Capital } \\
\text { in Wage Eqn }\end{array}$ & $\begin{array}{l}\text { Human Capital } \\
\text { out of Wage Eqn }\end{array}$ \\
\hline Full Specification & 0.0102 & 0.0279 & 0.0231 & 0.0537 \\
\hline Exclude Industry, Occupation, Govt & 0.0065 & 0.0263 & 0.0187 & 0.053 \\
\hline \multicolumn{5}{|l|}{ Exclude Industry, Occupation, Govt, Human } \\
\hline Capital Vars. & 0.0259 & 0.0653 & 0.0469 & 0.1075 \\
\hline B. United States and Australia not in Sample & \multicolumn{2}{|c|}{$\begin{array}{l}\text { perm*CBCOV, perm*PRODREG } \\
\text { Interactions Excluded from } \\
\text { Job Content Equations }\end{array}$} & \multicolumn{2}{|c|}{$\begin{array}{c}\text { perm*CBCOV, perm*PRODREG } \\
\text { Interactions Included in } \\
\text { Job Content Equations }\end{array}$} \\
\hline Job Content Models & $\begin{array}{l}\text { Human Capital } \\
\text { in Wage Eqn }\end{array}$ & $\begin{array}{l}\text { Human Capital } \\
\text { out of Wage Eqn }\end{array}$ & $\begin{array}{l}\text { Human Capital } \\
\text { in Wage Eqn }\end{array}$ & $\begin{array}{l}\text { Human Capital } \\
\text { out of Wage Eqn }\end{array}$ \\
\hline Full Specification & 0.0045 & 0.0154 & 0.0169 & 0.0403 \\
\hline Exclude Industry, Occupation, Govt & 0.0023 & 0.0135 & 0.0126 & 0.0374 \\
\hline \multicolumn{5}{|l|}{ Exclude Industry, Occupation, Govt, Human } \\
\hline Capital Vars. & 0.0057 & 0.0227 & 0.0221 & 0.0571 \\
\hline
\end{tabular}

Entries are: $\Sigma j(b j c j) *(3.0833-1.1714)$, where for each job content variable $j, b j$ is the corresponding interaction coefficient for perm*EPL from the equation with job content variable $\mathrm{j}$ as dependent variable, and $\mathrm{cj}$ is the coefficient for job content variable $\mathrm{j}$ from the indicated wage equation. 
Table 7: Selected Regression Results for Job Content Variables, Based on Separate Individual Country Regressions of Job Content on Permanent Employment and Controls

\begin{tabular}{|c|c|c|c|c|c|c|c|c|}
\hline \multicolumn{7}{|c|}{ Men and Women Pooled in Individual Country Regressions } & \multirow{3}{*}{$\begin{array}{l}\text { Task } \\
\text { Discretion }\end{array}$} & \multirow{3}{*}{$\begin{array}{l}\text { Task } \\
\text { Discretion }\end{array}$} \\
\hline & Influence & Influence & Reading & Reading & Writing & Writing & & \\
\hline \multicolumn{7}{|l|}{ Variable } & & \\
\hline \multirow[t]{2}{*}{ EPL } & $0.0990^{* *}$ & 0.0772 & $0.1811^{* *}$ & $0.2545^{* *}$ & $0.1270^{* *}$ & $0.1158^{*}$ & 0.0445 & 0.0686 \\
\hline & $(0.0334)$ & $(0.0475)$ & $(0.0344)$ & $(0.0486)$ & $(0.0328)$ & $(0.0428)$ & $(0.0443)$ & (0.0530) \\
\hline \multirow[t]{2}{*}{ CBCOV } & & 0.0511 & & $-0.1304+$ & & -0.0125 & & -0.0445 \\
\hline & & $(0.0797)$ & & $(0.0670)$ & & $(0.0514)$ & & (0.0668) \\
\hline \multirow[t]{2}{*}{ PRODREG } & & 0.0015 & & $-0.0572 *$ & & 0.0491 & & $-0.0168+$ \\
\hline & & $(0.0234)$ & & $(0.0267)$ & & (0.0394) & & (0.0095) \\
\hline $\mathrm{N}$ & 21 & 21 & 21 & 21 & 21 & 21 & 21 & 21 \\
\hline \multirow[t]{2}{*}{ Adjusted R squared } & 0.2762 & 0.2168 & 0.5298 & 0.6028 & 0.3809 & 0.3957 & 0.0499 & -0.023 \\
\hline & Planning & Planning & Numeracy & Numeracy & ICT & ICT & & \\
\hline \multirow[t]{2}{*}{ EPL } & $0.1091^{* *}$ & $0.1162^{*}$ & 0.0358 & 0.0610 & $-0.1002 * *$ & -0.0354 & & \\
\hline & $(0.0372)$ & $(0.0526)$ & $(0.0589)$ & $(0.0753)$ & $(0.0279)$ & $(0.0526)$ & & \\
\hline \multirow[t]{2}{*}{ CBCOV } & & -0.0059 & & -0.0880 & & -0.1197 & & \\
\hline & & (0.0768) & & $(0.1020)$ & & $(0.0964)$ & & \\
\hline \multirow[t]{2}{*}{ PRODREG } & & -0.0138 & & 0.0343 & & $-0.0450^{*}$ & & \\
\hline & & $(0.0154)$ & & $(0.0221)$ & & $(0.0181)$ & & \\
\hline $\mathrm{N}$ & 21 & 21 & 21 & 21 & 21 & 21 & & \\
\hline Adjusted R squared & 0.2985 & 0.2228 & -0.0255 & -0.0486 & 0.2139 & 0.2651 & & \\
\hline
\end{tabular}

$+,{ }^{*}, *$ denote significant at $10 \%, 5 \%$ and $1 \%$ level, respectively.

Entries are regression coefficients where the dependent variable is the perm coefficient from individual country regressions of the indicated job content variable on permanent employment and controls. Controls include a female dummy, years of schooling, experience and its square, numeracy and literacy test scores, an immigrant indicator, government employment, industry and occupation. Standard errors are heteroskedasticity-robust. 


\section{APPENDIX TABLES}

1. Table A1: Job Content by Country by Contract Type

2. Table A2: Personal Characteristics by Contract Type by Country

3. Table A3: Selected Log Hourly Earnings Regression Results, Wage and Salary Workers, Pooled Sample of 20 Countries

4. Table A4: Job Content Regression Results, Sample Pooled by Country and Gender

5. Table A5: Selected Regression Results for Job Content Variables, Pooled 19

Country Sample, USA out (Men and Women Pooled) 


\section{Reading}

Country Temporary Sample Size Permanent Sample Size Diff (Perm-Temp)

$\begin{array}{lcclcc}\text { Australia } & 2.482 & 511 & 2.308 & 2,914 & -0.174 \\ \text { Austria } & 1.976 & 234 & 2.061 & 2,465 & 0.085 \\ \text { Belgium } & 1.868 & 146 & 1.945 & 2,433 & 0.077 \\ \text { Britain } & 2.317 & 460 & 2.181 & 3,447 & -0.137 \\ \text { Czech } & 1.711 & 474 & 1.880 & 2,119 & 0.169 \\ \text { Denmark } & 1.956 & 416 & 2.149 & 3,874 & 0.193 \\ \text { Estonia } & 1.909 & 486 & 1.973 & 3,706 & 0.064 \\ \text { Finland } & 2.101 & 436 & 2.192 & 2,764 & 0.091 \\ \text { France } & 1.556 & 313 & 1.869 & 3,055 & 0.313 \\ \text { Ireland } & 1.990 & 404 & 2.109 & 1,982 & 0.119 \\ \text { Italy } & 1.340 & 214 & 1.637 & 1,484 & 0.297 \\ \text { Japan } & 1.902 & 591 & 2.157 & 2,494 & 0.254 \\ \text { Korea } & 2.080 & 530 & 2.361 & 1,501 & 0.281 \\ \text { Netherlands } & 1.746 & 508 & 2.144 & 2,450 & 0.398 \\ \text { Norway } & 2.017 & 309 & 2.273 & 2,569 & 0.256 \\ \text { Poland } & 1.587 & 1,351 & 1.919 & 1,885 & 0.332 \\ \text { Russia } & 1.728 & 318 & 1.634 & 1,124 & -0.095 \\ \text { Slovak } & 1.536 & 288 & 1.816 & 1,994 & 0.280 \\ \text { Spain } & 1.585 & 362 & 2.023 & 1,674 & 0.438 \\ \text { Sweden } & 1.992 & 284 & 2.223 & 2,426 & 0.231 \\ \text { USA } & 2.695 & 300 & 2.281 & 760 & -0.414 \\ \text { Total } & 1.933 & 8,935 & 2.059 & 49,120 & 0.126 \\ & & & \text { Writing } & & \end{array}$

Temporary Sample Size Permanent Sample Size Diff (Perm-Temp)

\begin{tabular}{lccccc} 
Australia & 2.396 & 499 & 2.265 & 2,790 & -0.131 \\
Austria & 1.969 & 202 & 2.115 & 2,307 & 0.146 \\
Belgium & 1.837 & 141 & 2.129 & 2,300 & 0.293 \\
Britain & 2.278 & 435 & 2.297 & 3,291 & 0.019 \\
Czech & 1.791 & 406 & 1.984 & 1,916 & 0.193 \\
Denmark & 1.809 & 374 & 2.005 & 3,656 & 0.196 \\
Estonia & 1.684 & 377 & 1.739 & 3,053 & 0.055 \\
Finland & 1.937 & 412 & 2.065 & 2,629 & 0.128 \\
France & 1.624 & 274 & 1.957 & 2,780 & 0.333 \\
Ireland & 2.052 & 376 & 2.304 & 1,881 & 0.251 \\
Italy & 1.636 & 169 & 1.842 & 1,278 & 0.206 \\
Japan & 2.169 & 557 & 2.354 & 2,410 & 0.185 \\
Korea & 2.453 & 473 & 2.645 & 1,401 & 0.191 \\
Netherlands & 1.830 & 460 & 2.209 & 2,368 & 0.380 \\
Norway & 1.949 & 287 & 2.164 & 2,498 & 0.214 \\
Poland & 1.945 & 1,045 & 2.062 & 1,617 & 0.117 \\
Russia & 1.723 & 291 & 1.966 & 974 & 0.242 \\
Slovak & 1.827 & 251 & 2.010 & 1,783 & 0.183 \\
Spain & 1.939 & 300 & 2.181 & 1,537 & 0.242 \\
Sweden & 1.740 & 247 & 1.895 & 2,284 & 0.155 \\
USA & 2.578 & 290 & 2.368 & 710 & -0.210 \\
Total & 2.025 & 7,866 & 2.123 & 45,463 & 0.099 \\
\hline
\end{tabular}




\section{Influence}

$\begin{array}{lccccc}\text { Country } & \text { Temporary } & \text { Sample Size } & \text { Permanent } & \text { Sample Size } & \text { Diff (Perm-Temp) } \\ \text { Australia } & 2.599 & 493 & 2.457 & 2,848 & -0.141 \\ \text { Austria } & 1.683 & 204 & 1.942 & 2,336 & 0.260 \\ \text { Belgium } & 1.756 & 133 & 1.951 & 2,248 & 0.195 \\ \text { Britain } & 2.324 & 457 & 2.311 & 3,363 & -0.013 \\ \text { Czech } & 1.799 & 443 & 1.881 & 2,030 & 0.082 \\ \text { Denmark } & 1.978 & 389 & 2.131 & 3,784 & 0.153 \\ \text { Estonia } & 1.934 & 460 & 2.009 & 3,571 & 0.075 \\ \text { Finland } & 2.326 & 433 & 2.292 & 2,728 & -0.034 \\ \text { France } & 1.763 & 269 & 1.939 & 2,852 & 0.176 \\ \text { Ireland } & 2.305 & 384 & 2.309 & 1,905 & 0.003 \\ \text { Italy } & 1.497 & 239 & 1.712 & 1,557 & 0.215 \\ \text { Japan } & 1.543 & 583 & 1.846 & 2,420 & 0.302 \\ \text { Korea } & 1.856 & 506 & 2.046 & 1,448 & 0.190 \\ \text { Netherlands } & 1.747 & 479 & 2.031 & 2,352 & 0.284 \\ \text { Norway } & 1.879 & 303 & 2.145 & 2,565 & 0.266 \\ \text { Poland } & 1.814 & 1,254 & 1.985 & 1,799 & 0.171 \\ \text { Russia } & 2.005 & 303 & 2.002 & 1,076 & -0.003 \\ \text { Slovak } & 1.724 & 228 & 1.840 & 1,602 & 0.117 \\ \text { Spain } & 1.560 & 371 & 1.857 & 1,613 & 0.297 \\ \text { Sweden } & 2.002 & 277 & 2.121 & 2,412 & 0.119 \\ \text { USA } & 2.847 & 290 & 2.342 & 760 & -0.504 \\ \text { Total } & 1.993 & 8,498 & 2.062 & 47,269 & 0.069 \\ \text { Country } & & & T a s k & & \end{array}$

Country

Task Discretion

Temporary Sample Size Permanent Sample Size Diff (Perm-Temp)

\begin{tabular}{lccccc} 
Australia & 1.736 & 504 & 1.762 & 2,879 & 0.025 \\
Austria & 1.967 & 248 & 2.232 & 2,307 & 0.265 \\
Belgium & 1.754 & 161 & 2.062 & 2,300 & 0.308 \\
Britain & 1.643 & 461 & 1.801 & 3,291 & 0.159 \\
Czech & 1.819 & 495 & 1.975 & 1,916 & 0.156 \\
Denmark & 2.003 & 424 & 2.228 & 3,656 & 0.224 \\
Estonia & 1.892 & 520 & 1.802 & 3,053 & -0.090 \\
Finland & 2.134 & 450 & 2.191 & 2,629 & 0.058 \\
France & 1.581 & 322 & 1.745 & 2,780 & 0.164 \\
Ireland & 1.476 & 400 & 1.618 & 1,881 & 0.142 \\
Italy & 1.285 & 246 & 1.519 & 1,278 & 0.234 \\
Japan & 2.054 & 634 & 2.215 & 2,410 & 0.161 \\
Korea & 1.605 & 512 & 1.726 & 1,401 & 0.121 \\
Netherlands & 1.636 & 537 & 1.872 & 2,368 & 0.236 \\
Norway & 1.827 & 314 & 2.065 & 2,498 & 0.238 \\
Poland & 1.666 & 1,435 & 1.822 & 1,617 & 0.156 \\
Russia & 1.450 & 317 & 1.496 & 974 & 0.045 \\
Slovak & 1.435 & 291 & 1.604 & 1,783 & 0.169 \\
Spain & 1.598 & 454 & 1.757 & 1,537 & 0.158 \\
Sweden & 1.946 & 290 & 2.186 & 2,284 & 0.240 \\
USA & 1.770 & 300 & 1.924 & 770 & 0.155 \\
Total & 1.710 & 9,315 & 1.899 & 49,766 & 0.189 \\
\hline
\end{tabular}




\section{Planning}

Country Temporary Sample Size Permanent Sample Size Diff (Perm-Temp)

$\begin{array}{lccccc}\text { Australia } & 2.323 & 481 & 2.329 & 2,745 & 0.007 \\ \text { Austria } & 1.691 & 219 & 1.927 & 2,394 & 0.236 \\ \text { Belgium } & 1.725 & 134 & 2.090 & 2,242 & 0.364 \\ \text { Britain } & 2.215 & 419 & 2.289 & 3,209 & 0.074 \\ \text { Czech } & 1.941 & 472 & 2.232 & 2,056 & 0.291 \\ \text { Denmark } & 1.726 & 394 & 2.096 & 3,819 & 0.370 \\ \text { Estonia } & 2.057 & 493 & 2.220 & 3,682 & 0.162 \\ \text { Finland } & 2.019 & 437 & 2.007 & 2,702 & -0.012 \\ \text { France } & 1.707 & 269 & 2.010 & 2,783 & 0.303 \\ \text { Ireland } & 2.181 & 356 & 2.302 & 1,809 & 0.121 \\ \text { Italy } & 1.772 & 253 & 2.022 & 1,546 & 0.249 \\ \text { Japan } & 1.380 & 511 & 1.604 & 2,260 & 0.223 \\ \text { Korea } & 1.741 & 508 & 1.855 & 1,464 & 0.114 \\ \text { Netherlands } & 1.839 & 438 & 2.138 & 2,317 & 0.300 \\ \text { Norway } & 1.631 & 293 & 1.929 & 2,489 & 0.299 \\ \text { Poland } & 1.941 & 1,303 & 2.166 & 1,890 & 0.226 \\ \text { Russia } & 1.899 & 308 & 1.959 & 1,075 & 0.060 \\ \text { Slovak } & 1.801 & 231 & 1.957 & 1,723 & 0.156 \\ \text { Spain } & 1.838 & 409 & 2.050 & 1,705 & 0.212 \\ \text { Sweden } & 1.878 & 272 & 2.076 & 2,363 & 0.197 \\ \text { USA } & 2.414 & 280 & 2.132 & 700 & -0.282 \\ \text { Total } & 1.923 & 8,480 & 2.069 & 46,973 & 0.136\end{array}$

Numeracy Skills

Temporary Sample Size Permanent Sample Size Diff (Perm-Temp)

\begin{tabular}{lccccc} 
Australia & 2.138 & 451 & 2.226 & 2,589 & 0.088 \\
Austria & 1.762 & 184 & 1.980 & 2,079 & 0.218 \\
Belgium & 1.892 & 111 & 1.912 & 1,889 & 0.020 \\
Britain & 1.998 & 371 & 2.130 & 2,945 & 0.132 \\
Czech & 1.896 & 434 & 2.164 & 1,982 & 0.268 \\
Denmark & 1.753 & 320 & 1.947 & 3,281 & 0.194 \\
Estonia & 1.776 & 394 & 2.016 & 3,206 & 0.241 \\
Finland & 1.945 & 386 & 2.158 & 2,563 & 0.213 \\
France & 1.714 & 222 & 2.028 & 2,456 & 0.314 \\
Ireland & 1.962 & 314 & 2.130 & 1,658 & 0.169 \\
Italy & 1.887 & 144 & 1.960 & 1,118 & 0.074 \\
Japan & 1.675 & 512 & 1.953 & 2,303 & 0.278 \\
Korea & 1.908 & 418 & 2.249 & 1,329 & 0.341 \\
Netherlands & 1.798 & 371 & 1.981 & 1,964 & 0.183 \\
Norway & 1.681 & 226 & 1.876 & 2,240 & 0.195 \\
Poland & 1.915 & 1,081 & 2.032 & 1,593 & 0.117 \\
Russia & 1.780 & 250 & 1.846 & 940 & 0.067 \\
Slovak & 2.096 & 222 & 2.100 & 1,677 & 0.004 \\
Spain & 1.715 & 269 & 2.120 & 1,406 & 0.405 \\
Sweden & 1.706 & 218 & 1.856 & 2,103 & 0.151 \\
USA & 2.275 & 270 & 2.335 & 680 & 0.060 \\
Total & 1.900 & 7,168 & 2.048 & 42,001 & 0.147 \\
\hline
\end{tabular}


Table A1 (ctd): Job Content by Country by Contract Type

\begin{tabular}{lccccc}
\hline Country & \multicolumn{5}{c}{ ICT Skills } \\
& Temporary & Sample Size & Permanent & Sample Size & Diff (Perm-Temp) \\
Australia & 2.129 & 445 & 2.237 & 2,325 & 0.108 \\
Austria & 1.994 & 163 & 1.940 & 1,896 & -0.054 \\
Belgium & 1.986 & 105 & 2.031 & 1,812 & 0.044 \\
Britain & 1.986 & 352 & 2.270 & 2,809 & 0.284 \\
Czech & 2.095 & 281 & 2.066 & 1,472 & -0.028 \\
Denmark & 1.895 & 326 & 2.122 & 3,181 & 0.226 \\
Estonia & 2.059 & 291 & 2.199 & 2,392 & 0.140 \\
Finland & 1.740 & 334 & 1.915 & 2,308 & 0.174 \\
France & 1.706 & 187 & 1.949 & 2,161 & 0.242 \\
Ireland & 1.937 & 274 & 2.213 & 1,525 & 0.276 \\
Italy & 2.121 & 105 & 2.118 & 996 & -0.003 \\
Japan & 1.424 & 379 & 1.786 & 1,848 & 0.362 \\
Korea & 2.078 & 374 & 2.484 & 1,196 & 0.406 \\
Netherlands & 1.847 & 361 & 2.136 & 2,077 & 0.289 \\
Norway & 1.597 & 236 & 1.978 & 2,225 & 0.381 \\
Poland & 1.876 & 704 & 2.064 & 1,197 & 0.188 \\
Russia & 1.855 & 191 & 1.839 & 673 & -0.016 \\
Slovak & 2.103 & 140 & 2.080 & 1,169 & -0.023 \\
Spain & 1.768 & 169 & 2.084 & 1,142 & 0.316 \\
Sweden & 1.650 & 213 & 1.898 & 2,122 & 0.247 \\
USA & 2.076 & 260 & 2.415 & 620 & 0.339 \\
Total & 1.910 & 5,890 & 2.087 & 37,146 & 0.177 \\
\hline & & & & &
\end{tabular}

Note: Total sample sizes reflect rounding of US sample sizes to the nearest 10. 


\section{Years of Schooling Completed}

Country Temporary Sample Size Permanent Sample Size Diff (Perm-Temp)

$\begin{array}{lccccc}\text { Australia } & 15.716 & 517 & 14.967 & 2,959 & -0.749 \\ \text { Austria } & 12.259 & 255 & 12.328 & 2,621 & 0.069 \\ \text { Belgium } & 13.060 & 165 & 13.021 & 2,563 & -0.039 \\ \text { Britain } & 13.355 & 479 & 13.249 & 3,526 & -0.106 \\ \text { Czech } & 13.429 & 524 & 13.482 & 2,215 & 0.053 \\ \text { Denmark } & 13.305 & 432 & 13.017 & 3,998 & -0.288 \\ \text { Estonia } & 12.820 & 527 & 12.587 & 3,899 & -0.233 \\ \text { Finland } & 13.348 & 450 & 12.984 & 2,796 & -0.364 \\ \text { France } & 11.924 & 355 & 11.883 & 3,232 & -0.041 \\ \text { Ireland } & 15.760 & 426 & 15.695 & 2,041 & -0.065 \\ \text { Italy } & 11.292 & 292 & 11.584 & 1,686 & 0.293 \\ \text { Japan } & 12.899 & 658 & 13.404 & 2,639 & 0.505 \\ \text { Korea } & 13.494 & 595 & 14.091 & 1,579 & 0.597 \\ \text { Netherlands } & 13.267 & 552 & 13.688 & 2,536 & 0.421 \\ \text { Norway } & 14.362 & 315 & 14.498 & 2,596 & 0.136 \\ \text { Poland } & 13.084 & 1,496 & 13.909 & 2,051 & 0.825 \\ \text { Russia } & 14.293 & 333 & 14.226 & 1,204 & -0.066 \\ \text { Slovak } & 13.608 & 349 & 13.882 & 2,135 & 0.274 \\ \text { Spain } & 11.364 & 504 & 12.588 & 1,891 & 1.223 \\ \text { Sweden } & 12.427 & 293 & 12.608 & 2,457 & 0.180 \\ \text { USA } & 15.329 & 300 & 14.294 & 790 & -1.034 \\ \text { Total } & 13.461 & 9,817 & 13.318 & 51,414 & -0.143\end{array}$

Years of Actual Labor Market Experience

Temporary Sample Size Permanent Sample Size Diff (Perm-Temp)

\begin{tabular}{lccccc} 
Australia & 16.978 & 517 & 18.967 & 2,959 & 1.989 \\
Austria & 10.216 & 255 & 19.720 & 2,307 & 9.504 \\
Belgium & 10.167 & 165 & 20.582 & 2,300 & 10.415 \\
Britain & 16.816 & 479 & 19.844 & 3,291 & 3.028 \\
Czech & 14.019 & 524 & 20.004 & 1,916 & 5.985 \\
Denmark & 14.009 & 432 & 22.501 & 3,656 & 8.492 \\
Estonia & 16.068 & 527 & 19.748 & 3,053 & 3.680 \\
Finland & 11.276 & 450 & 20.106 & 2,629 & 8.830 \\
France & 11.195 & 355 & 20.238 & 2,780 & 9.043 \\
Ireland & 14.661 & 426 & 18.153 & 1,881 & 3.492 \\
Italy & 12.141 & 292 & 19.203 & 1,278 & 7.062 \\
Japan & 20.311 & 658 & 18.337 & 2,410 & -1.974 \\
Korea & 12.415 & 595 & 13.797 & 1,401 & 1.382 \\
Netherlands & 10.263 & 552 & 21.171 & 2,368 & 10.909 \\
Norway & 10.617 & 315 & 19.730 & 2,498 & 9.113 \\
Poland & 12.040 & 1,496 & 18.501 & 1,617 & 6.461 \\
Russia & 19.150 & 333 & 17.678 & 974 & -1.472 \\
Slovak & 13.068 & 349 & 19.690 & 1,783 & 6.622 \\
Spain & 12.106 & 504 & 19.170 & 1,537 & 7.064 \\
Sweden & 11.161 & 293 & 21.405 & 2,284 & 10.244 \\
USA & 21.735 & 300 & 20.514 & 790 & -1.221 \\
Total & 14.371 & 9,817 & 19.550 & 51,414 & 5.179 \\
\hline
\end{tabular}




\section{Numeracy Test Score}

Country Temporary Sample Size Permanent Sample Size Diff (Perm-Temp)

$\begin{array}{lccccc}\text { Australia } & 288.105 & 517 & 279.014 & 2,959 & -9.09 \\ \text { Austria } & 281.045 & 255 & 279.490 & 2,621 & -1.56 \\ \text { Belgium } & 288.458 & 165 & 287.224 & 2,563 & -1.23 \\ \text { Britain } & 264.151 & 479 & 277.153 & 3,526 & 13.00 \\ \text { Czech } & 276.153 & 524 & 279.706 & 2,215 & 3.55 \\ \text { Denmark } & 283.538 & 432 & 286.403 & 3,998 & 2.86 \\ \text { Estonia } & 272.389 & 527 & 277.533 & 3,899 & 5.14 \\ \text { Finland } & 293.102 & 450 & 290.811 & 2,796 & -2.29 \\ \text { France } & 255.077 & 355 & 262.366 & 3,232 & 7.29 \\ \text { Ireland } & 259.668 & 426 & 268.032 & 2,041 & 8.36 \\ \text { Italy } & 247.595 & 292 & 256.076 & 1,686 & 8.48 \\ \text { Japan } & 285.149 & 658 & 293.861 & 2,639 & 8.71 \\ \text { Korea } & 270.884 & 595 & 273.256 & 1,579 & 2.37 \\ \text { Netherlands } & 287.957 & 552 & 286.792 & 2,536 & -1.16 \\ \text { Norway } & 272.698 & 315 & 287.466 & 2,596 & 14.77 \\ \text { Poland } & 261.385 & 1,496 & 270.001 & 2,051 & 8.62 \\ \text { Russia } & 280.867 & 333 & 272.939 & 1,204 & -7.93 \\ \text { Slovak } & 279.437 & 349 & 286.272 & 2,135 & 6.84 \\ \text { Spain } & 246.695 & 504 & 260.585 & 1,891 & 13.89 \\ \text { Sweden } & 278.464 & 293 & 287.651 & 2,457 & 9.19 \\ \text { USA } & 272.938 & 300 & 267.777 & 790 & -5.16 \\ \text { Total } & 272.410 & 9,817 & 277.932 & 51,414 & 5.52\end{array}$

Country

Literacy Test Score

Temporary Sample Size Permanent Sample Size Diff (Perm-Temp)

\begin{tabular}{lccccc} 
Australia & 300.074 & 517 & 290.608 & 2,959 & -9.47 \\
Austria & 281.396 & 255 & 274.063 & 2,621 & -7.33 \\
Belgium & 289.188 & 165 & 282.625 & 2,563 & -6.56 \\
Britain & 279.635 & 479 & 284.977 & 3,526 & 5.34 \\
Czech & 277.308 & 524 & 277.850 & 2,215 & 0.54 \\
Denmark & 280.234 & 432 & 277.658 & 3,998 & -2.58 \\
Estonia & 280.460 & 527 & 278.813 & 3,899 & -1.65 \\
Finland & 301.167 & 450 & 295.398 & 2,796 & -5.77 \\
France & 266.268 & 355 & 267.240 & 3,232 & 0.97 \\
Ireland & 271.445 & 426 & 278.081 & 2,041 & 6.64 \\
Italy & 246.173 & 292 & 256.460 & 1,686 & 10.29 \\
Japan & 291.757 & 658 & 301.463 & 2,639 & 9.71 \\
Korea & 277.042 & 595 & 280.924 & 1,579 & 3.88 \\
Netherlands & 294.178 & 552 & 290.164 & 2,536 & -4.01 \\
Norway & 280.707 & 315 & 285.280 & 2,596 & 4.57 \\
Poland & 269.019 & 1,496 & 276.361 & 2,051 & 7.34 \\
Russia & 281.979 & 333 & 279.047 & 1,204 & -2.93 \\
Slovak & 275.967 & 349 & 280.989 & 2,135 & 5.02 \\
Spain & 255.701 & 504 & 263.980 & 1,891 & 8.28 \\
Sweden & 279.581 & 293 & 288.567 & 2,457 & 8.99 \\
USA & 286.430 & 300 & 280.320 & 790 & -6.11 \\
Total & 278.672 & 9,817 & 280.542 & 51,414 & 1.87 \\
\hline
\end{tabular}




\section{Incidence of Managerial Jobs}

Country Temporary Sample Size Permanent Sample Size Diff (Perm-Temp)

$\begin{array}{lccccc}\text { Australia } & 0.112 & 517 & 0.122 & 2,959 & 0.010 \\ \text { Austria } & 0.033 & 255 & 0.061 & 2,621 & 0.028 \\ \text { Belgium } & 0.036 & 165 & 0.083 & 2,563 & 0.047 \\ \text { Britain } & 0.057 & 479 & 0.129 & 3,526 & 0.072 \\ \text { Czech } & 0.040 & 524 & 0.062 & 2,215 & 0.022 \\ \text { Denmark } & 0.044 & 432 & 0.062 & 3,998 & 0.018 \\ \text { Estonia } & 0.050 & 527 & 0.087 & 3,899 & 0.037 \\ \text { Finland } & 0.015 & 450 & 0.041 & 2,796 & 0.027 \\ \text { France } & 0.024 & 355 & 0.092 & 3,232 & 0.069 \\ \text { Ireland } & 0.026 & 426 & 0.074 & 2,041 & 0.048 \\ \text { Italy } & 0.010 & 292 & 0.013 & 1,686 & 0.004 \\ \text { Japan } & 0.033 & 658 & 0.083 & 2,639 & 0.050 \\ \text { Korea } & 0.029 & 595 & 0.039 & 1,579 & 0.010 \\ \text { Netherlands } & 0.051 & 552 & 0.124 & 2,536 & 0.073 \\ \text { Norway } & 0.014 & 315 & 0.088 & 2,596 & 0.075 \\ \text { Poland } & 0.033 & 1,496 & 0.095 & 2,051 & 0.062 \\ \text { Russia } & 0.110 & 333 & 0.073 & 1,204 & -0.037 \\ \text { Slovak } & 0.032 & 349 & 0.062 & 2,135 & 0.029 \\ \text { Spain } & 0.008 & 504 & 0.041 & 1,891 & 0.034 \\ \text { Sweden } & 0.026 & 293 & 0.064 & 2,457 & 0.038 \\ \text { USA } & 0.078 & 300 & 0.104 & 790 & 0.026 \\ \text { Total } & 0.043 & 9,817 & 0.076 & 51,414 & 0.033\end{array}$

Incidence of Professional/Technical Jobs

Temporary Sample Size Permanent Sample Size Diff (Perm-Temp)

\begin{tabular}{lccccc} 
Australia & 0.508 & 517 & 0.380 & 2,959 & -0.129 \\
Austria & 0.420 & 255 & 0.372 & 2,621 & -0.047 \\
Belgium & 0.422 & 165 & 0.402 & 2,563 & -0.020 \\
Britain & 0.351 & 479 & 0.305 & 3,526 & -0.047 \\
Czech & 0.300 & 524 & 0.302 & 2,215 & 0.002 \\
Denmark & 0.446 & 432 & 0.436 & 3,998 & -0.010 \\
Estonia & 0.371 & 527 & 0.368 & 3,899 & -0.003 \\
Finland & 0.422 & 450 & 0.418 & 2,796 & -0.004 \\
France & 0.343 & 355 & 0.375 & 3,232 & 0.032 \\
Ireland & 0.365 & 426 & 0.386 & 2,041 & 0.021 \\
Italy & 0.242 & 292 & 0.321 & 1,686 & 0.079 \\
Japan & 0.222 & 658 & 0.302 & 2,639 & 0.080 \\
Korea & 0.294 & 595 & 0.330 & 1,579 & 0.036 \\
Netherlands & 0.333 & 552 & 0.429 & 2,536 & 0.096 \\
Norway & 0.390 & 315 & 0.419 & 2,596 & 0.029 \\
Poland & 0.270 & 1,496 & 0.388 & 2,051 & 0.119 \\
Russia & 0.384 & 333 & 0.407 & 1,204 & 0.023 \\
Slovak & 0.288 & 349 & 0.382 & 2,135 & 0.094 \\
Spain & 0.244 & 504 & 0.320 & 1,891 & 0.075 \\
Sweden & 0.361 & 293 & 0.446 & 2,457 & 0.085 \\
USA & 0.606 & 300 & 0.456 & 790 & -0.150 \\
Total & 0.356 & 9,817 & 0.378 & 51,414 & 0.023 \\
\hline Total samp & $5125 r e f 1$ & & & \\
\end{tabular}

Total sample sizes reflect rounding of US sample size to the nearest 10. 
Table A3: Selected Log Hourly Earnings Regression Results, Wage and Salary Workers, Pooled Sample of 21 Countries

\begin{tabular}{|c|c|c|c|c|c|c|}
\hline \multirow[b]{2}{*}{ Female } & \multicolumn{2}{|c|}{ Men and Women Pooled } & & \multirow[t]{2}{*}{ Men } & \multicolumn{2}{|c|}{ Women } \\
\hline & $\begin{array}{l}-0.1621^{* *} \\
(0.0186)\end{array}$ & $\begin{array}{l}-0.1549 * * \\
(0.0176)\end{array}$ & & & & \\
\hline Years of Schooling & & $\begin{array}{l}0.0486 * * \\
(0.0039)\end{array}$ & & $\begin{array}{l}0.0433^{* *} \\
(0.0040)\end{array}$ & & $\begin{array}{l}0.0532 * * \\
(0.0044)\end{array}$ \\
\hline Experience & & $\begin{array}{l}0.0293 * * \\
(0.0029)\end{array}$ & & $\begin{array}{l}0.0349 * * \\
(0.0036)\end{array}$ & & $\begin{array}{l}0.0244 * * \\
(0.0027)\end{array}$ \\
\hline Experience Squared & & $\begin{array}{l}-0.0004^{* *} \\
(0.0000)\end{array}$ & & $\begin{array}{l}-0.0005^{* *} \\
(0.0001)\end{array}$ & & $\begin{array}{l}-0.0003^{* *} \\
(0.0000)\end{array}$ \\
\hline Numeracy Test Score & & $\begin{array}{l}0.0011 * * \\
(0.0001)\end{array}$ & & $\begin{array}{l}0.0012^{* *} \\
(0.0002)\end{array}$ & & $\begin{array}{l}0.0011^{* *} \\
(0.0002)\end{array}$ \\
\hline Literacy Test Score & & $\begin{array}{l}0.0005^{* *} \\
(0.0002)\end{array}$ & & $\begin{array}{c}0.0006+ \\
(0.0003)\end{array}$ & & $\begin{array}{l}0.0005^{* *} \\
(0.0001)\end{array}$ \\
\hline Immigrant & & $\begin{array}{l}-0.0417^{*} \\
(0.0195)\end{array}$ & & $\begin{array}{l}-0.0235 \\
(0.0203)\end{array}$ & & $\begin{array}{l}-0.0578 * \\
(0.0221)\end{array}$ \\
\hline Influence & $\begin{array}{l}0.0336 * \\
(0.0118)\end{array}$ & $\begin{array}{l}0.0195+ \\
(0.0100)\end{array}$ & $\begin{array}{l}0.0285 \\
(0.0168)\end{array}$ & $\begin{array}{l}0.0117 \\
(0.0144)\end{array}$ & $\begin{array}{l}0.0329 * * \\
(0.0081)\end{array}$ & $\begin{array}{l}0.0223^{* *} \\
(0.0072)\end{array}$ \\
\hline Reading & $\begin{array}{l}0.0726^{* *} \\
(0.0104)\end{array}$ & $\begin{array}{l}0.0261^{* *} \\
(0.0089)\end{array}$ & $\begin{array}{l}0.0592^{* *} \\
(0.0103)\end{array}$ & $\begin{array}{l}0.0179+ \\
(0.0094)\end{array}$ & $\begin{array}{l}0.0848^{* *} \\
(0.0128)\end{array}$ & $\begin{array}{l}0.0345^{* *} \\
(0.0114)\end{array}$ \\
\hline Writing & $\begin{array}{l}0.0030 \\
(0.0097)\end{array}$ & $\begin{array}{l}0.0075 \\
(0.0080)\end{array}$ & $\begin{array}{l}0.0015 \\
(0.0112)\end{array}$ & $\begin{array}{l}0.0088 \\
(0.0091)\end{array}$ & $\begin{array}{l}0.0058 \\
(0.0107)\end{array}$ & $\begin{array}{l}0.0063 \\
(0.0088)\end{array}$ \\
\hline Task Discretion & $\begin{array}{l}0.0512^{* *} \\
(0.0051)\end{array}$ & $\begin{array}{l}0.0345^{* *} \\
(0.0050)\end{array}$ & $\begin{array}{l}0.0601^{* *} \\
(0.0067)\end{array}$ & $\begin{array}{l}0.0351^{* *} \\
(0.0066)\end{array}$ & $\begin{array}{l}0.0402 * * \\
(0.0061)\end{array}$ & $\begin{array}{l}0.0320^{* *} \\
(0.0059)\end{array}$ \\
\hline Planning & $\begin{array}{l}0.0069 \\
(0.0082)\end{array}$ & $\begin{array}{l}-0.0013 \\
(0.0057)\end{array}$ & $\begin{array}{l}0.0048 \\
(0.0121)\end{array}$ & $\begin{array}{l}0.0012 \\
(0.0094)\end{array}$ & $\begin{array}{l}0.0108 \\
(0.0064)\end{array}$ & $\begin{array}{l}-0.0041 \\
(0.0049)\end{array}$ \\
\hline Numeracy & $\begin{array}{l}0.0000 \\
(0.0043)\end{array}$ & $\begin{array}{l}0.0033 \\
(0.0044)\end{array}$ & $\begin{array}{l}0.0152 * \\
(0.0057)\end{array}$ & $\begin{array}{l}0.0176^{*} \\
(0.0062)\end{array}$ & $\begin{array}{l}-0.0159 * \\
(0.0063)\end{array}$ & $\begin{array}{l}-0.0080 \\
(0.0053)\end{array}$ \\
\hline ICT & $\begin{array}{l}0.0724^{* *} \\
(0.0089)\end{array}$ & $\begin{array}{l}0.0477^{* *} \\
(0.0065)\end{array}$ & $\begin{array}{l}0.0761^{* *} \\
(0.0096)\end{array}$ & $\begin{array}{l}0.0500 * * \\
(0.0061)\end{array}$ & $\begin{array}{l}0.0687^{* *} \\
(0.0106)\end{array}$ & $\begin{array}{l}0.0462 * * \\
(0.0092)\end{array}$ \\
\hline $\mathrm{N}$ & 33803 & 33803 & 16174 & 16174 & 17629 & 17629 \\
\hline Adjusted R squared & 0.4365 & 0.5378 & 0.3694 & 0.4835 & 0.4749 & 0.5619 \\
\hline
\end{tabular}

$+, *, * *$ denote significant at $10 \%, 5 \%$ and $1 \%$ level, respectively.

Sample includes only those with hourly earnings values greater than or equal to $\$ 2$ and less than or equal to $\$ 500$.

Regressions also include country dummy variables. Adjusted sampling weights are used with each country receiving equal weight. Standard errors clustered at the country level. Sample sizes reflect rounding of US sample sizes to the nearest 10. 
Table A4: Job Content Regression Results, Sample Pooled by Country and Gender

\begin{tabular}{|c|c|c|c|c|}
\hline & Influence & Reading & Writing & $\begin{array}{l}\text { Task } \\
\text { Discretion }\end{array}$ \\
\hline Years of Schooling & $\begin{array}{c}0.0422^{* *} \\
(0.0036)\end{array}$ & $\begin{array}{l}0.0692^{* *} \\
(0.0046)\end{array}$ & $\begin{array}{l}0.0441^{* *} \\
(0.0030)\end{array}$ & $\begin{array}{l}0.0223^{* *} \\
(0.0024)\end{array}$ \\
\hline Immigrant & $\begin{array}{c}-0.0918^{* *} \\
(0.0202)\end{array}$ & $\begin{array}{c}-0.0654^{* *} \\
(0.0199)\end{array}$ & $\begin{array}{c}0.0038 \\
(0.0175)\end{array}$ & $\begin{array}{l}-0.0627^{* *} \\
(0.0128)\end{array}$ \\
\hline Female & $\begin{array}{c}-0.1877^{* *} \\
(0.0130)\end{array}$ & $\begin{array}{c}-0.1925^{* *} \\
(0.0156)\end{array}$ & $\begin{array}{c}-0.1389 * * \\
(0.0170)\end{array}$ & $\begin{array}{l}-0.0683^{* *} \\
(0.0125)\end{array}$ \\
\hline Experience & $\begin{array}{c}0.0194^{* *} \\
(0.0026)\end{array}$ & $\begin{array}{l}0.0146^{* *} \\
(0.0023)\end{array}$ & $\begin{array}{l}0.0143^{* *} \\
(0.0025)\end{array}$ & $\begin{array}{l}0.0117^{* *} \\
(0.0024)\end{array}$ \\
\hline Experience Squared & $\begin{array}{c}-0.0004^{* *} \\
(0.0001)\end{array}$ & $\begin{array}{c}-0.0003^{* *} \\
(0.0000)\end{array}$ & $\begin{array}{c}-0.0003^{* *} \\
(0.0000)\end{array}$ & $\begin{array}{l}-0.0001^{* *} \\
(0.0000)\end{array}$ \\
\hline Numeracy Test Score & $\begin{array}{l}0.0010^{*} \\
(0.0004)\end{array}$ & $\begin{array}{c}0.0009 * * \\
(0.0003)\end{array}$ & $\begin{array}{c}0.0004 \\
(0.0003)\end{array}$ & $\begin{array}{l}0.0007^{*} \\
(0.0003)\end{array}$ \\
\hline Literacy Test Score & $\begin{array}{l}-0.0006 \\
(0.0004)\end{array}$ & $\begin{array}{l}-0.0001 \\
(0.0003)\end{array}$ & $\begin{array}{c}0.0001 \\
(0.0003)\end{array}$ & $\begin{array}{l}-0.0000 \\
(0.0003)\end{array}$ \\
\hline Government Employment & $\begin{array}{l}-0.0055 \\
(0.0198)\end{array}$ & $\begin{array}{c}0.0697^{* *} \\
(0.0128)\end{array}$ & $\begin{array}{l}-0.0069 \\
(0.0173)\end{array}$ & $\begin{array}{l}-0.1474^{* *} \\
(0.0154)\end{array}$ \\
\hline Mining/Construction & $\begin{array}{l}0.1267^{*} \\
(0.0512)\end{array}$ & $\begin{array}{c}0.0713 \\
(0.0461)\end{array}$ & $\begin{array}{l}0.1258^{*} \\
(0.0495)\end{array}$ & $\begin{array}{l}0.0300 \\
(0.0562)\end{array}$ \\
\hline Manufacturing & $\begin{array}{c}0.0384 \\
(0.0590)\end{array}$ & $\begin{array}{c}0.0235 \\
(0.0344)\end{array}$ & $\begin{array}{l}0.1693^{* *} \\
(0.0427)\end{array}$ & $\begin{array}{l}-0.0491 \\
(0.0530)\end{array}$ \\
\hline Transportation/Commun. & $\begin{array}{c}0.0138 \\
(0.0612)\end{array}$ & $\begin{array}{l}0.1620^{* *} \\
(0.0421)\end{array}$ & $\begin{array}{l}0.2437^{* *} \\
(0.0427)\end{array}$ & $\begin{array}{l}-0.0395 \\
(0.0532)\end{array}$ \\
\hline Trade & $\begin{array}{c}0.2294^{* *} \\
(0.0455)\end{array}$ & $\begin{array}{l}0.1546^{* *} \\
(0.0416)\end{array}$ & $\begin{array}{c}0.0731 \\
(0.0475)\end{array}$ & $\begin{array}{l}0.0006 \\
(0.0541)\end{array}$ \\
\hline Food Service and Hotels & $\begin{array}{l}0.1800^{* *} \\
(0.0504)\end{array}$ & $\begin{array}{c}-0.1268^{*} \\
(0.0573)\end{array}$ & $\begin{array}{l}-0.0693 \\
(0.0561)\end{array}$ & $\begin{array}{l}-0.0462 \\
(0.0542)\end{array}$ \\
\hline Finance, Ins., Real Est. & $\begin{array}{l}0.1499^{*} \\
(0.0550)\end{array}$ & $\begin{array}{l}0.3108^{* *} \\
(0.0473)\end{array}$ & $\begin{array}{l}0.3191^{* *} \\
(0.0520)\end{array}$ & $\begin{array}{l}-0.0260 \\
(0.0546)\end{array}$ \\
\hline Prof., Admin Svcs. & $\begin{array}{l}-0.0336 \\
(0.0550)\end{array}$ & $\begin{array}{l}0.1553^{* *} \\
(0.0349)\end{array}$ & $\begin{array}{l}0.2609 * * \\
(0.0381)\end{array}$ & $\begin{array}{l}0.0194 \\
(0.0598)\end{array}$ \\
\hline Public Admin & $\begin{array}{c}0.0426 \\
(0.0590)\end{array}$ & $\begin{array}{l}0.2152^{* *} \\
(0.0346)\end{array}$ & $\begin{array}{l}0.3583^{* *} \\
(0.0474)\end{array}$ & $\begin{array}{l}-0.0124 \\
(0.0500)\end{array}$ \\
\hline Education & $\begin{array}{l}0.5864^{* *} \\
(0.0650)\end{array}$ & $\begin{array}{l}0.2095 * * \\
(0.0389)\end{array}$ & $\begin{array}{c}0.0418 \\
(0.0465)\end{array}$ & $\begin{array}{l}-0.0829 \\
(0.0590)\end{array}$ \\
\hline Health & $\begin{array}{l}0.1416^{*} \\
(0.0662)\end{array}$ & $\begin{array}{l}0.0681+ \\
(0.0386)\end{array}$ & $\begin{array}{l}0.3708^{* *} \\
(0.0461)\end{array}$ & $\begin{array}{l}-0.1517^{*} \\
(0.0539)\end{array}$ \\
\hline Other Svcs. & $\begin{array}{l}0.0959+ \\
(0.0484)\end{array}$ & $\begin{array}{l}0.1267^{* *} \\
(0.0418)\end{array}$ & $\begin{array}{c}0.0083 \\
(0.0550)\end{array}$ & $\begin{array}{l}0.1375^{*} \\
(0.0633)\end{array}$ \\
\hline
\end{tabular}


Table A4: Job Content Regression Results, Sample Pooled by Country and Gender (ctd)

\begin{tabular}{|c|c|c|c|c|}
\hline & Influence & Reading & Writing & $\begin{array}{l}\text { Task } \\
\text { Discretion }\end{array}$ \\
\hline \multirow[t]{2}{*}{ Manager } & $1.2656^{* *}$ & $1.2150 * *$ & $1.0902 * *$ & $0.6835^{* *}$ \\
\hline & $(0.0462)$ & (0.0519) & $(0.0598)$ & $(0.0341)$ \\
\hline \multirow[t]{2}{*}{ Professional } & $0.8727^{* *}$ & $1.1163^{* *}$ & $0.8700^{* *}$ & $0.3119 * *$ \\
\hline & $(0.0371)$ & $(0.0464)$ & $(0.0371)$ & $(0.0327)$ \\
\hline \multirow[t]{2}{*}{ Technical Occ. } & $0.7327^{* *}$ & $0.9930 * *$ & $0.8809 * *$ & $0.2930 * *$ \\
\hline & $(0.0350)$ & $(0.0455)$ & $(0.0412)$ & $(0.0353)$ \\
\hline \multirow[t]{2}{*}{ Clerical } & $0.4481^{* *}$ & $0.8270^{* *}$ & $0.7252^{* *}$ & $0.1781^{* *}$ \\
\hline & $(0.0497)$ & $(0.0468)$ & $(0.0372)$ & $(0.0359)$ \\
\hline \multirow[t]{2}{*}{ Sales, Serv. Occ. } & $0.5854^{* *}$ & $0.6047^{* *}$ & $0.5411^{* *}$ & $0.0646^{*}$ \\
\hline & $(0.0334)$ & $(0.0377)$ & (0.0339) & $(0.0289)$ \\
\hline \multirow[t]{2}{*}{ Skilled Agric Occ } & $0.3321 * *$ & $0.4205^{* *}$ & $0.2380^{* *}$ & 0.1117 \\
\hline & $(0.0652)$ & $(0.0740)$ & $(0.0744)$ & $(0.0705)$ \\
\hline \multirow[t]{2}{*}{ Craft } & $0.2220^{* *}$ & $0.3783^{* *}$ & $0.3448^{* *}$ & -0.0283 \\
\hline & $(0.0300)$ & $(0.0351)$ & $(0.0389)$ & $(0.0275)$ \\
\hline \multirow[t]{2}{*}{ Operative } & 0.0050 & $0.2247^{* *}$ & $0.2369 * *$ & $-0.2618^{* *}$ \\
\hline & $(0.0363)$ & $(0.0348)$ & $(0.0369)$ & $(0.0292)$ \\
\hline \multirow[t]{2}{*}{ Permanent Job (Perm) } & $-0.3427^{*}$ & $-0.3934 * *$ & $-0.3487 * *$ & 0.0457 \\
\hline & (0.1289) & $(0.0953)$ & $(0.0966)$ & $(0.0987)$ \\
\hline \multirow[t]{2}{*}{ Perm*EPL } & $0.2076^{* *}$ & $0.2754 * *$ & $0.1639 * *$ & 0.0141 \\
\hline & $(0.0698)$ & $(0.0514)$ & $(0.0495)$ & $(0.0476)$ \\
\hline \multirow[t]{2}{*}{ Perm*CBCOV } & -0.0620 & $-0.1428+$ & 0.0310 & 0.0041 \\
\hline & (0.1104) & $(0.0794)$ & $(0.0721)$ & $(0.0747)$ \\
\hline \multirow[t]{2}{*}{ Perm*PRODREG } & -0.0340 & $-0.0760 * *$ & 0.0153 & -0.0074 \\
\hline & (0.0209) & (0.0189) & $(0.0584)$ & $(0.0115)$ \\
\hline $\mathrm{N}$ & 55767 & 58055 & 53319 & 59081 \\
\hline Adjusted R sq & .2674 & .3591 & 0.2093 & 0.1692 \\
\hline
\end{tabular}


Table A4: Job Content Regression Results, Sample Pooled by Country and Gender (ctd)

\begin{tabular}{|c|c|c|c|}
\hline & Planning & Numeracy & ICT \\
\hline Years of Schooling & $\begin{array}{c}0.0204 * * \\
(0.0032)\end{array}$ & $\begin{array}{c}0.0406 * * \\
(0.0033)\end{array}$ & $\begin{array}{c}0.0520 * * \\
(0.0044)\end{array}$ \\
\hline Immigrant & $\begin{array}{c}-0.0742 * * \\
(0.0219)\end{array}$ & $\begin{array}{l}0.0505^{*} \\
(0.0220)\end{array}$ & $\begin{array}{c}0.0820 * * \\
(0.0211)\end{array}$ \\
\hline Female & $\begin{array}{c}-0.0670 * * \\
(0.0131)\end{array}$ & $\begin{array}{c}-0.1641 * * \\
(0.0249)\end{array}$ & $\begin{array}{c}-0.1090 * * \\
(0.0146)\end{array}$ \\
\hline Experience & $\begin{array}{c}0.0234^{* *} \\
(0.0031)\end{array}$ & $\begin{array}{c}0.0072^{* *} \\
(0.0020)\end{array}$ & $\begin{array}{c}0.0120 * * \\
(0.0032)\end{array}$ \\
\hline Experience Squared & $\begin{array}{c}-0.0004^{* *} \\
(0.0001)\end{array}$ & $\begin{array}{c}-0.0002 * * \\
(0.0000)\end{array}$ & $\begin{array}{c}-0.0003^{* *} \\
(0.0001)\end{array}$ \\
\hline Numeracy Test Score & $\begin{array}{c}0.0008 * * \\
(0.0003)\end{array}$ & $\begin{array}{c}0.0039 * * \\
(0.0003)\end{array}$ & $\begin{array}{l}0.0009 * \\
(0.0004)\end{array}$ \\
\hline Literacy Test Score & $\begin{array}{l}-0.0001 \\
(0.0003)\end{array}$ & $\begin{array}{c}-0.0017^{* *} \\
(0.0004)\end{array}$ & $\begin{array}{l}0.0010 * \\
(0.0004)\end{array}$ \\
\hline Government Employment & $\begin{array}{c}-0.0469 * \\
(0.0208)\end{array}$ & $\begin{array}{c}-0.1235^{* *} \\
(0.0158)\end{array}$ & $\begin{array}{c}-0.1541^{* *} \\
(0.0226)\end{array}$ \\
\hline Mining/Construction & $\begin{array}{l}0.1477^{*} \\
(0.0598)\end{array}$ & $\begin{array}{l}0.2034^{* *} \\
(0.0399)\end{array}$ & $\begin{array}{c}0.3010 * * \\
(0.0609)\end{array}$ \\
\hline Manufacturing & $\begin{array}{c}0.0474 \\
(0.0653)\end{array}$ & $\begin{array}{l}0.2113^{* *} \\
(0.0421)\end{array}$ & $\begin{array}{c}0.2475 * * \\
(0.0626)\end{array}$ \\
\hline Transportation/Commun. & $\begin{array}{c}0.0036 \\
(0.0787)\end{array}$ & $\begin{array}{l}-0.0085 \\
(0.0378)\end{array}$ & $\begin{array}{c}0.3783 * * \\
(0.0636)\end{array}$ \\
\hline Trade & $\begin{array}{c}0.0416 \\
(0.0608)\end{array}$ & $\begin{array}{l}0.2515^{* *} \\
(0.0403)\end{array}$ & $\begin{array}{l}0.1568 * \\
(0.0647)\end{array}$ \\
\hline Food Service and Hotels & $\begin{array}{l}0.1843 * \\
(0.0759)\end{array}$ & $\begin{array}{c}0.0625 \\
(0.0445)\end{array}$ & $\begin{array}{c}0.0081 \\
(0.0758)\end{array}$ \\
\hline Finance, Ins., Real Est. & $\begin{array}{l}-0.0695 \\
(0.0710)\end{array}$ & $\begin{array}{c}0.3162 * * \\
(0.0515)\end{array}$ & $\begin{array}{c}0.4557^{* *} \\
(0.0671)\end{array}$ \\
\hline Prof., Admin Svcs. & $\begin{array}{l}-0.0686 \\
(0.0653)\end{array}$ & $\begin{array}{c}0.1439 * * \\
(0.0404)\end{array}$ & $\begin{array}{c}0.3300 * * \\
(0.0543)\end{array}$ \\
\hline Public Admin & $\begin{array}{c}-0.0281 \\
(0.0696)\end{array}$ & $\begin{array}{c}-0.2007^{* *} \\
(0.0423)\end{array}$ & $\begin{array}{c}0.2920 * * \\
(0.0600)\end{array}$ \\
\hline Education & $\begin{array}{c}0.2695^{* *} \\
(0.0804)\end{array}$ & $\begin{array}{c}-0.2605^{* *} \\
(0.0445)\end{array}$ & $\begin{array}{c}0.0220 \\
(0.0624)\end{array}$ \\
\hline Health & $\begin{array}{c}0.0831 \\
(0.0694)\end{array}$ & $\begin{array}{c}-0.4163^{* *} \\
(0.0426)\end{array}$ & $\begin{array}{c}-0.2194^{* *} \\
(0.0617)\end{array}$ \\
\hline Other Svcs. & $\begin{array}{l}-0.0003 \\
(0.0658)\end{array}$ & $\begin{array}{c}-0.2610^{* *} \\
(0.0523) \\
\end{array}$ & $\begin{array}{l}0.1488^{*} \\
(0.0631)\end{array}$ \\
\hline
\end{tabular}


Table A4: Job Content Regression Results, Sample Pooled by Country and Gender (ctd)

\begin{tabular}{lccc}
\hline & Planning & Numeracy & ICT \\
Manager & & & \\
& $0.8944^{* *}$ & $0.9938^{* *}$ & $1.1693^{* *}$ \\
Professional & $(0.0514)$ & $(0.0463)$ & $(0.0615)$ \\
& $0.4692^{* *}$ & $0.7337^{* *}$ & $0.8744^{* *}$ \\
Technical Occ. & $(0.0376)$ & $(0.0434)$ & $(0.0494)$ \\
& $0.4253^{* *}$ & $0.7727^{* *}$ & $0.8618^{* *}$ \\
Clerical & $(0.0307)$ & $(0.0408)$ & $(0.0539)$ \\
& $0.2379^{* *}$ & $0.7140^{* *}$ & $0.8445^{* *}$ \\
Sales, Serv. Occ. & $(0.0369)$ & $(0.0355)$ & $(0.0690)$ \\
& $0.1932^{* *}$ & $0.3702^{* *}$ & $0.3244^{* *}$ \\
Skilled Agric Occ & $(0.0288)$ & $(0.0253)$ & $(0.0458)$ \\
& $0.3830^{* *}$ & $0.1946^{*}$ & $0.2662^{*}$ \\
Craft & $(0.0697)$ & $(0.0692)$ & $(0.1254)$ \\
& $0.1198^{* *}$ & $0.0715^{*}$ & 0.0364 \\
Operative & $(0.0206)$ & $(0.0323)$ & $(0.0534)$ \\
& -0.0224 & $0.0752+$ & $-0.1787^{* *}$ \\
Permanent Job (Perm) & $(0.0304)$ & $(0.0407)$ & $(0.0469)$ \\
& $-0.3233^{* *}$ & -0.1544 & $0.3133^{* *}$ \\
Perm*EPL & $(0.0711)$ & $(0.1013)$ & $(0.0601)$ \\
& $0.1999^{* *}$ & $0.1131+$ & -0.0201 \\
Perm*CBCOV & $(0.0441)$ & $(0.0588)$ & $(0.0561)$ \\
& -0.0598 & -0.1332 & -0.1401 \\
Perm*PRODREG & $(0.0725)$ & $(0.0859)$ & $(0.1106)$ \\
& -0.0168 & 0.0201 & -0.0541 \\
N & $(0.0151)$ & $(0.0236)$ & $(0.0354)$ \\
Adjusted R sq & 55453 & 49179 & 43036 \\
\hline$*$ & 0.1281 & 0.2224 & 0.282 \\
\hline & & &
\end{tabular}

$+,{ }^{*}, * *$ denote significant at $10 \%, 5 \%$ and $1 \%$ level, respectively.

Regressions also include country dummy variables. Adjusted sampling weights are used with each country receiving equal weight. Standard errors clustered at the country level. The omitted industry is agriculture, and the omitted occupation is elementary occupations. Sample sizes reflect rounding of US sample size to the nearest 10. 
Table A5: Selected Regression Results for Job Content Variables, Pooled 19 Country Sample, USA and Australia Out (Men and Women Pooled)

\begin{tabular}{|c|c|c|c|c|c|c|c|c|}
\hline & Influence & Influence & Reading & Reading & Writing & Writing & $\begin{array}{c}\text { Task } \\
\text { Discretion }\end{array}$ & $\begin{array}{c}\text { Task } \\
\text { Discretion }\end{array}$ \\
\hline \multicolumn{9}{|l|}{ Variable } \\
\hline \multirow[t]{2}{*}{ perm } & -0.0575 & -0.0514 & -0.1983 & -0.2140 & -0.1336 & -0.1025 & -0.1193 & -0.1178 \\
\hline & (0.1308) & (0.1394) & (0.1479) & $(0.1652)$ & $(0.1065)$ & $(0.1121)$ & $(0.1140)$ & (0.1096) \\
\hline \multirow[t]{2}{*}{ perm*EPL } & 0.0592 & 0.0879 & $0.1197+$ & $0.2021^{* *}$ & $0.0959 *$ & 0.0580 & 0.0770 & 0.0782 \\
\hline & $(0.0505)$ & $(0.0625)$ & $(0.0571)$ & $(0.0668)$ & $(0.0444)$ & $(0.0539)$ & $(0.0454)$ & $(0.0462)$ \\
\hline \multirow[t]{2}{*}{ perm*CBCOV } & & -0.0357 & & $-0.1201+$ & & 0.0691 & & -0.0010 \\
\hline & & $(0.0940)$ & & $(0.0660)$ & & $(0.0671)$ & & $(0.0711)$ \\
\hline \multirow[t]{2}{*}{ perm*PRODREG } & & $-0.0387+$ & & $-0.0800 * *$ & & 0.0146 & & -0.0028 \\
\hline & & $(0.0185)$ & & $(0.0191)$ & & $(0.0564)$ & & $(0.0097)$ \\
\hline $\mathrm{N}$ & 51376 & 51376 & 53570 & 53570 & 49040 & 49040 & 54628 & 54628 \\
\hline \multirow[t]{2}{*}{ Adjusted R squared } & 0.2553 & 0.2553 & 0.3584 & 0.3587 & 0.2046 & 0.2046 & 0.1726 & 0.1725 \\
\hline & Planning & Planning & Numeracy & Numeracy & ICT & ICT & & \\
\hline \multirow[t]{2}{*}{ perm } & $-0.1946+$ & -0.2096 & 0.1132 & 0.0340 & $0.3723^{*}$ & $0.3290^{*}$ & & \\
\hline & $(0.0940)$ & $(0.1236)$ & $(0.1687)$ & $(0.1461)$ & $(0.1476)$ & $(0.1346)$ & & \\
\hline \multirow[t]{2}{*}{ perm*EPL } & $0.1250 * *$ & $0.1566^{*}$ & -0.0147 & 0.0344 & $-0.1066+$ & -0.0253 & & \\
\hline & $(0.0373)$ & $(0.0654)$ & $(0.0683)$ & $(0.0689)$ & $(0.0577)$ & $(0.0734)$ & & \\
\hline \multirow[t]{2}{*}{ perm*CBCOV } & & -0.0528 & & -0.1169 & & -0.1305 & & \\
\hline & & $(0.0813)$ & & $(0.0772)$ & & $(0.1116)$ & & \\
\hline \multirow[t]{2}{*}{ perm*PRODREG } & & $-0.0216+$ & & 0.0187 & & -0.0552 & & \\
\hline & & $(0.0122)$ & & $(0.0244)$ & & $(0.0323)$ & & \\
\hline $\mathrm{N}$ & 51247 & 51247 & 45179 & 45179 & 39386 & 39386 & & \\
\hline Adjusted R squared & 0.1204 & 0.1204 & 0.2258 & 0.2259 & 0.2766 & 0.2767 & & \\
\hline
\end{tabular}

,$+ * * *$ significant at $10 \%, 5 \%$ and $1 \%$ levels, respectively.

Controls include years of schooling, experience and its square, immigrant dummy, numeracy test score, literacy test score, government employment dummy, industry, occupation and country dummies, and a female dummy variable.

Adjusted sampling weights used, where each country receives the same weight. Standard errors clustered at the country level. 